\title{
5403 Sayılı Kanun Çerçevesinde Terekedeki Tarım Arazilerinin Devredilmesi Karşısında Muris Muvazaası
}

\author{
A. Nilay Șenol ${ }^{\star}$ (i), Özge Uzun Kazmacı* (1)
}

Öz

5403 sayılı Toprak Koruma ve Arazi Kullanımı Kanunu, tarım arazilerinin bütünlüğünün korunması ve miras yolu ile tarım arazilerinin bölünmesinin önüne geçilmesini amaçlamaktadır. Bu Kanun çerçevesinde, terekedeki tarım arazisinin, öncelikle mirasçıların kendi aralarında anlaşarak içlerinden birine veya birkaçına, aile malları ortaklığına, limited şirkete ya da üçüncü bir kişiye bırakılması; mirasçılar kendi aralarında anlaşamazlarsa sulh hâkimi tarafindan tarım arazisinin ehil bir mirasçıya bırakılması veya arazinin satışına karar verilmesi düzenlenmektedir. Ayrıca yine bu Kanun’a göre, ölüme bağlı tasarruf yoluyla da tarım arazisinin bırakılacağı ehil mirasçı belirlenebilmektedir. Mirasbırakanın sağlığında, mirasçılardan birine tarım arazisini devretmesi de yasal sınırlar içinde mümkün ve geçerlidir. Ancak bu devir, muvazaalı bir işlemle gerçekleştiğinde, muris muvazaasının söz konusu olup olmayacağı tartışmalıdır. Muris muvazaası, Yargıtay İçtihadı Birleştirme Kararları ile bazı ilkelere bağlanmıştır. Öğretide ilgili Yargıtay kararları çeşitli açılardan eleştirilmekle birlikte uygulamada muris muvazaası davaları yıllardır Yargıtay'ın belirlediği kıstaslar çerçevesinde çözümlenmektedir. 5403 sayılı Kanun'un amacı ve ilgili düzenlemeleri de muris muvazaasının tespitinde dikkate alınması gereken bir kıstas olarak karşımıza çıkmaktadır.

Anahtar Kelimeler

Tarım arazisi, Toprak koruma, Ehil mirasçı, Muvazaa, Muris muvazaası

Testator's Simulation Before the Transfer of the Agricultural Lands in Succession within the Scope of Law Numbered 5403

\begin{abstract}
The Law on Protection of Soil and Land Use, numbered 5403, aims to protect the unity of agricultural lands, and to prevent the division of the soil with inheritance. This law stipulates first, the possibility regarding the giving over of the agricultural land in succession to one or more heirs, to a family partnership, to a limited liability company or to a third person with the consensus of the heirs and second, in case of disagreement, the judge shall decide whether to leave the agricultural land to a competent heir or to sell the land. Furthermore, according to this law, the competent heir to whom the agricultural land will be left can be determined by means of testamentary disposition. It is possible and also valid within the legal constraints that the testator can also transfer the agricultural land to one of the heirs while he is alive. It is arguable whether this transaction can be considered as the testator's simulation or not, if this transaction has also been made with a simulated transaction. Some principles are set out by the Supreme Court in terms of the simulation of the testator, and although these principles and decisions are criticized by the doctrine, such cases are held by these principles. The purpose and the regulations of the Law numbered 5403 shall be taken into consideration in determining testator's simulation.
\end{abstract}

\section{Keywords}

Agricultural land, Soil protection, Competent heir, Simulation, Testator's simulation

Sorumlu Yazar: A. Nilay Şenol (Dr. Öğr. Üyesi.), Yakın Doğu Üniversitesi, Girne Üniversitesi, Hukuk Fakültesi Medeni Hukuk Anabilim Dalı, Lefkoşa, KKTC. E-posta: aysenilay.senol@neu.edu.tr ORCID: 0000-0001-7144-9698

** Özge Uzun Kazmacı (Dr. Öğr. Üyesi.), Kadir Has Üniversitesi, Hukuk Fakültesi, Medeni Hukuk Anabilim Dalı İstanbul, Türkiye. E-posta: ozge.kazmaci@khas.edu.tr ORCID: 0000-0001-6916-8563

Atıf: Senol AN, Uzun-Kazmacı O, “5403 Sayılı Kanun Çerçevesinde Terekedeki Tarım Arazilerinin Devredilmesi Karşısında Muris Muvazaası” (2020) 78(1) İstanbul Hukuk Mecmuası 161. https://doi.org/10.26650/mecmua.2020.78.1.0006 


\section{Extended Summary}

The Law on Protection of Soil and Land Use, numbered 5403, aims to protect the unity of agricultural lands, and to prevent the division of the soil from becoming an unfruitful land with inheritance. Under this law, the agricultural land in succession is preferred to be left to one or more heirs. It is obvious that in order to protect the unity of agricultural lands, the law makes compromises from the principles of property right and right of succession.

By taking into account the aim of this law and the related provision within the inheritance law, the importance of the giving over of the agricultural lands to the competent heir can be understood. When the testator determines the competent heir in a testamentary disposition, one should act upon the will of the testator on condition that the heir is actually competent to operate the agricultural lands.

The testator may transfer the agricultural rights while he is still alive, on condition that it is not an infringement of the provisions of abatement. Gratuitous contracts are valid within the scope of provisions of abatement and hotchpot rules. The testator may have done these gratuitous contracts as simulated contracts. In accordance with the unified decisions of the supreme courts dated 1974, unless the intention of the testator for the property abduction from the other inheritors is detected, one should act upon the will of the testator and the contract is accepted as valid.

The unified decisions of the supreme courts dated 1974 have been criticized on the grounds of the priority of the will of the testator, testamentary freedom, and provisions in favour of the statutory heirs. It is also criticized that the heirs cannot claim unlawfulness and invalidity of form where the testator does not have this right in accordance with the essential principle that "every person must act in good faith in the exercise of his or her rights and in the performance of his or her obligations" and "the manifest abuse of a right is not protected by law".

Although the decision of the court is arguable, it is possible to reinterpret the decisions in light of the developments of the provisions of the Civil Code and other laws, and prevent the undesirable results. The unity of the agricultural lands, testator's freedom of testament and within this freedom, testator's will regarding the determination of the competent heir, should be taken into account while doing this reinterpretation.

The principles of priority of testator's will and freedom of testament may be preferred, whereas the heirs may file a case against the testator's simulated act.

On the other hand, where the subject of the simulated act is an agricultural land and the party of the act is the competent heir, in our opinion, it is not possible to interpret the act as testator's simulation by taking into consideration the aim and the 
compulsory provisions of the Law on Protection of Soil and Land Use even if the plaintiff is the statutory heir. In such cases, the heirs are very well preserved with the provisions of abatement and hotchpot rules.

If the agricultural land was transferred to a non-competent heir by a simulated contract and there are one or more competent heirs among others who are willing to operate the agricultural land, it is more appropriate to claim for a rectification of land registry with a ground of testator's simulation, and to include the agricultural land in the succession. In fact, the Law numbered 5403 aims to prevent the division of agricultural lands and to ensure that the lands are to be left to the competent heir. 


\section{Sayılı Kanun Çerçevesinde Terekedeki Tarım Arazilerinin Devredilmesi Karşısında Muris Muvazaası}

\section{Giriş}

Mirasbırakanın terekesinde tarım arazilerinin ve/veya tarım işletmelerinin bulunması durumunda bunlara ilişkin paylaşımın ne şekilde yapılacağı önem arz etmektedir. Tarım arazilerinin miras yoluyla parçalanması, sürdürülebilirliği ve verimi etkilediğinden kanun koyucu, emredici nitelikte hükümler içeren ve mülkiyet devri olarak adlandırdığı sistemi, tarım arazileri bakımından yeniden düzenlemiştir.

Tarım arazilerinin korunmasına ilişkin olarak 5403 sayılı ve 3.7.2005 tarihli Toprak Koruma ve Arazi Kullanımı Kanunu (TKAKK) hükümlerinde, 6537 sayılı Kanun ${ }^{1}$ ile değişiklik yapılmıştır. Bu değişiklik ile 4721 sayılı Türk Medenî Kanunu'nun 659 ile 668 arasındaki maddeleri yürürlükten kaldırılmıştır.

4721 sayılı Kanun'da yer alan hükümler, emredici hükümler olmadığından işlevsellik sağlayamamıştır. 5403 sayılı Kanun'da² 6537 sayılı Kanun ile yapılan değişiklikler sonucunda, tarım arazilerinde mülkiyetin devri sistemi benimsenmiştir. $\mathrm{Bu}$ sistem uyarınca Kanun'da belirtilen seçeneklerden biri uygulanacak ve tarım arazisinin mülkiyeti devredilecektir. Bu sistemin miras hukukunda hâkim olan, eşitlik, aynen paylaşma ve irade özgürlüğü ilkelerine bir istisna getirdiği söylenebilir.

6537 sayılı Kanun düzenlemesi ile tarım arazilerinin miras yoluyla intikaline ilişkin tamamlayıcı hükümler yerine emredici hükümler getirilmiştir. 6537 sayılı Kanun'un geçici 5. maddesi³ ${ }^{3}$, Kanun'un yürürlüğe girmesinden önce ölümün gerçekleştiği ve fakat paylaşımın yapılmadığı veya açılmış paylaşma davasının halen devam ettiği hallerde eski kanun hükümlerinin uygulanacağını belirtmiştir. Bu durumda, Türk Medeni Kanunu'nun yürürlüğe girdiği 01.01.2002 ile 6537 sayılı Kanun'la getirilen değişikliklerin yürürlüğe girdiği 15.05.2014 tarihleri arasında gerçekleşen ölümlere, TMK 659-668 arasındaki hükümler uygulanacaktır. O halde Kanun'un yayım tarihi olan 15.05.2014 tarihinden önce açılmış miraslarda, henüz paylaşım yapılmamışsa veya aynı tarihten önce açılmış ve halen devam etmekte olan davalarda, TMK hükümleri uygulanabilecek; bu tarihten sonra açılan miraslarda ise

Toprak Koruma ve Arazi Kullanımı Kanunu'nda Değişiklik Yapılması Hakkında Kanun, Kanun Numarası: 6537, Kabul tarihi: 30.4.2014, RG 15.05.2014/29001.

25403 sayılı Kanun'da daha önce de 31.01.2007 tarih ve 5578 sayılı Toprak Koruma ve Arazi Kullanımı Kanunu'nda Değişiklik Yapılması Hakkında Kanun ile değişiklik yapılmıştır. 5403 sayılı Kanun’un 8. maddesinde 5578 sayılı Kanun ile yapılan değişiklik, tarımsal faaliyetin ekonomik olarak yapılabildiği en küçük alana sahip ve daha fazla küçülmemesi gereken yeter büyüklükteki tarımsal arazi parsel büyüklüğünün belirlenmesi ve belirlenen küçüklüğe erişmiş tarımsal arazilerin miras hukuku bakımından bölünemez eşya niteliği kazanmasını esas almaktaydı. TMK'nın özgülemeye ilişkin hükümlerinin kıyasen uygulanacağı da belirtilmekteydi.

3 "Bu maddenin yayımı tarihinde mirasçılar arasında henüz paylaşımı yapılmamış tarımsal arazilerin devir işlemleri, bu maddeyi ihdas eden Kanundan önceki kanun hükümlerine göre tamamlanır. Bu maddenin yayımı tarihinden önce tarımsal arazilerin paylaşımına iliş̧kin olarak açılmış ve hâlen devam etmekte olan davalarda, bu maddeyi ihdas eden Kanundan önceki kanun hükümleri uygulanır. Bu maddenin yayımı tarihinden itibaren iki yıl içinde birinci fikraya göre yapılacak devir işlemleri harçlardan müstesnadır. Bu süre Bakanlar Kurulu tarafindan iki yıl uzatılabilir.” 
yeni sistem uygulanacaktır ${ }^{4}$. Çalışmamızda, yeni sistem esas alınarak açıklamalarda bulunulacaktır. Bu çalışma kapsamında, ayrıca 3083 sayılı Sulama Alanlarında Arazi Düzenlenmesine Dair Tarım Reformu Kanunu incelenmemiştir. Bu Kanun kapsamına giren tarım arazileri bakımından ölüm tarihine bakılmaksızın 3083 sayılı Kanun hükümleri uygulama alanı bulacaktır.

5403 sayılı Kanun ile amaçlanan, bu Kanun kapsamındaki tarım arazilerinin bütünlüğünün korunmasıdır. $\mathrm{Bu}$ çerçevede miras yolu ile tarım arazilerinin bölünmesinin önüne geçmek ve tarım arazilerinin ehil bir ya da birkaç mirasçı tarafindan yönetilebilmesi için düzenlemeler getirilmiştir. Bu çalışmada, ilgili düzenlemeler dikkate alınarak, mirasbırakanın sağlığında tarım arazilerine ilişkin yaptığı muvazaalı işlemlerde, muris muvazaasının koşullarının gerçekleşip gerçekleşmediği değerlendirilecektir.

Çalışma kapsamında öncelikle 5403 sayılı Kanun çerçevesinde tarım arazilerinin miras yoluyla geçişi ve bu geçişte aranan kıstaslar incelenmiş, ardından söz konusu düzenlemelerin muris muvazaasına etkisi değerlendirilmiştir. $\mathrm{Bu}$ değerlendirme öncesinde, genel olarak muvazaa ve özellikle muris muvazaası da incelenmiştir.

\section{5403 Sayılı Toprak Koruma ve Arazi Kullanımı Kanunu Çerçevesinde Terekedeki Tarım Arazilerinin Devri}

\section{A. Genel Olarak}

Anayasanın 44. maddesi uyarınca devlet, toprağın verimli olarak işletilmesini korumak ve geliştirmek, erozyonla kaybedilmesini önlemek ve topraksız olan veya yeter toprağı bulunmayan çiftçilikle uğraşan köylüye toprak sağlamak amacıyla gerekli tedbirleri alır. 5403 sayılı Kanun ile tarımın, tarım işletmelerinin sürekliliğini sağlamak, toprakların parçalanmasını ve dolayısıyla verimliliklerini kaybetmelerini önlemek amacıyla miras hukukundaki temel ilkelerin aksine ve paylaşma kurallarına istisna olacak şekilde tarım arazilerinin devri düzenlenmiştir. Tarım arazilerinin küçülmesini ve bölünmesini engellemek için düzenlemeler getirildiği de Kanun'un genel gerekçesinde ifade edilmiştir ${ }^{5}$. Bu düzenlemeler uyarınca 5403 sayılı Kanun, tarım arazilerini, doğal özellikleri ve ülke tarımındaki önemine göre mutlak tarım arazileri, özel ürün arazileri, dikili tarım arazileri ve marjinal tarım arazileri olarak siniflandirmaktadır (madde 8 ve 3).

\footnotetext{
Yargıtay'ın geçici 5. maddeye aykırı olarak yeni kanun hükümlerini uyguladığı kararları da bulunmaktadır. “...Ne var ki, hükümden sonra 15/5/2014 tarihinde yürürlüğe giren 30.04.2014 tarihli ve 6537 sayll Yasa ile 5403 sayll Yasanin 8. maddesi değiştirilmiş ve ilave hükümler getirilmişstir. Hemen belirtilmelidir ki; kural olarak sonradan yürürlüğe giren Kanun hükümlerinin kesin hüküm halini almamış davalarda gözetilmesi gerekeceği kuşkusuzdur. Hal böyle olunca, 5403 sayll Yasanın 8. maddesinde değişiklik yapan ve bir kısım ilaveler getiren 6537 sayıl Yasa hükümleri ile yapılan değişiklikler değerlendirilerek bir karar verilmesi için hüküm bozulmalıdır”. (Yargıtay 1 HD, 15284/18510, 27.11.2014, Kazancı İçtihat Bilgi Bankası). Aynı şekilde bkz Yargıtay 14 HD, 7183/10805, 02.10.2014, Kazancı İçtihat Bilgi Bankası.

Genel Gerekçe, https://www.tbmm.gov.tr/sirasayi/donem24/yi101/ss564.pdf.
} 
5403 sayılı Kanun'un değişik 8/B maddesine göre, "Mirasa konu tarımsal arazi ve yeter gelirli tarımsal arazilerde mülkiyetin devri esastır. Mirasçllar arasında anlaşma sağlanması hâlinde, mülkiyeti devir işlemleri mirasın açılmasından itibaren bir yıl içinde tamamlanır. Devir işlemlerinin bir yıl içinde tamamlanmaması ve 8/C maddesinin ikinci fikrasına göre dava açılmaması hâlinde, bu Kanunun 8/Ç maddesi hükümleri uygulanır".

6537 sayılı Kanun ile 5403 sayılı Kanun'da yapılan değişiklikle "özgüleme” yerine "mülkiyetin devri" sistemi benimsenmiştir'. Türk Medeni Kanunu'nun 659 ile 668. maddeleri arasında, tarımsal işletmelerin özgülenmesi hüküm altına alınmışt1 ${ }^{7}$. 6537 sayılı Kanun ile bu hükümler ilga edilmiştir. Bu düzenlemelerde esas olan, "tarımsal işletme" ve "özgüleme" ifadeleriydi. Mülga 659. maddeye göre, "Terekede bulunan, ekonomik bütünlüğe ve yeterli tarımsal varlı̆̆a sahip bir tarımsal işletme, işletmeye ehil mirasçllardan birinin istemde bulunması halinde bu mirasçıya gelir değeri üzerinden bölünmeksizin özgülenir" denilmekteydi.

5403 sayılı Kanun'un 8/C hükmü uyarınca, tarım arazileri miras hukuku kuralları çerçevesinde mirasçılar arasında paylaşılmayacaktır ve Kanun hükümleri uyarınca tek bir mirasçıya, belirli koşullarda birden fazla mirasçıya, aile malları ortaklığına, bir limited şirkete veya üçüncü bir kişiye devredilebilecektir ${ }^{8}$. Mirasbırakanın ölümü ile tarım arazileri miras ortaklığına geçmektedir; ancak 5403 sayılı Kanun'un öngördüğü seçeneklerden biri ile devredilmesi emredici hale gelmiştir ${ }^{9}$ Tarım arazilerinin devrinin de, özgüleme gibi, miras hukuku anlamında paylaşma olarak nitelendirilebileceği belirtilmiştir ${ }^{10}$. Tarım arazisinin terekede yer alan tek değer olması durumunda, miras ortaklığı da sona ereceği için tam paylaşmadan; tarım

\footnotetext{
Cevdet Yavuz ve Murat Topuz, ‘Toprak Koruma ve Arazi Kullanımı Kanununda Değişiklik Yapılması Hakkında Kanun’un Türk Medeni Kanunu'nun Miras Hukukuna İlişkin Hükümlerinde Yaptığı Değişiklikler' (2015) 21(2) MÜHFHAD (Mehmet Akif Aydın'a Armağan) 663, 672-674'te özgüleme sistemi yerine devir sisteminin getirilmesi amacıyla yapılan değişikliklerin kaynağı ve yerindeliği eleştirilmektedir. Yazarlar, genel gerekçede yer alan "tarımsal özel miras hukukunun başlıca iki sistemi olarak işletmenin tek bir mirasçıya verilmesi ya da mirasçılardan birine özgülenmesi biçimlerinden bahsedilebilir" ifadesini, TMK'da özgüleme sisteminden başka bir sistem olmaması ve genel gerekçede belirtilen miras hukuku sisteminin tek mirasçıya geçişe uygun olmadığı tespitinin doğru olmaması sebepleri ile eleştirmektedirler. Genel Gerekçede, "Tasarı ile, tarım arazileri ve işletmeler ile ilgili mevcut sistem tamamen değiștirilmiştir" denilmişse de, bir sistem değişikliğinin meydana getirilmediği de vurgulanmıştır. Aynı yönde bkz Ömer Bağcı, 'Tarımsal Arazilerin Miras Yoluyla İntikali’ iç Tuğçe Tuzcuoğlu ve A Hulki Cihan (edr), Yargıtay Kararları Işı̆̆̆ında Güncel Medeni Hukuk Problemleri Sempozyumu Bildirileri 8-9 Kasım 2018 (On İki Levha 2019) 459-460.

TMK 659 vd hükümlerinde ve İsviçre hukuk sisteminde yapılan değişiklikler için bkz Yavuz ve Topuz (n 8) 665 vd.

8 TKAKK 8/D hükmü uyarınca mülkiyetin devri kendilerine yapılmayan mirasçı veya mirasçılara miras paylarının ödenmesi söz konusudur. Bu ödemenin hukuki niteliğine ilişkin olarak, miras payının ödenmesi, ikame değer veya tazminat görüşleri bulunmaktadır. Bu görüsşler için bkz Kemal Erdoğan, 'Tarım Arazilerinin Miras Yoluyla İntikali' (2016) 24(1) Selçuk Üniversitesi Hukuk Fakültesi Dergisi 123, 168; Alper Uyumaz ve Onur İlhan, 'Tarımsal Arazilerde Mülkiyetin Devri' (2018) 24(2) MÜHFHAD 861, 877-878.

Kanun hükmü uyarınca, sulh hukuk hâkimi, mülkiyetin devrini uygun bulduğu mirasçıya, diğer mirasçıların miras paylarının bedelini mahkeme veznesine depo etmek üzere altı aya kadar süre verir. Mirasçı tarafindan talep edilmesi hâlinde altı ay ek süre verilebilir. Hükümde, bu süreler zarfında tarımsal arazinin akıbetinin ne olacağına ilișkin bir düzenleme bulunmamaktadır. Bu süreler içerisinde tarım arazisinin atıl kalmaması için TKAKK 8/G hükmünün kıyasen uygulanabileceği, TMK 640/3 veya TMK 550 hükümlerinin uygulanabileceği konusunda bkz Uyumaz ve İlhan (n 10) 878.

9 O Levent Özay, Tarım İşletmelerinin ve Arazilerinin Miras Yoluyla İntikali (Yetkin 2015) 152.

10 Özay (n 11) 152.
} 
arazisinin yanı sıra başka değerlerin de bulunması durumunda ise kısmi paylaşmadan bahsedilebilecektir ${ }^{11}$.

Kanun'un 8/F maddesi de "ölüme bağl1 tasarruf ile düzenleme" kenar başlığ1 ile şu hükmü içermektedir: "Yeter gelirli tarımsal arazi mülkiyetinin kendisine devredilmesini isteyen ve buna ehil tek mirasçı olduğu anlaşılan mirasçının bu konudaki istem hakkl, ölüme bağlı tasarrufla ortadan kaldırılamaz. Mirastan çıkarma, mirastan yoksunluk ve mirastan feragat hâlleri saklıdır. Birden çok mirasçıda devir koşullarının bulunması hâlinde, kendisine devir yapılacak mirasçı ölüme bağlı tasarrufla belirlenebilir. Belirlenen bu mirasçıya itiraz edilmesi durumunda, ehil mirasçı sulh hukuk hâkimi tarafindan belirlenir""l2.

Hükmün ilk fikrası, mirasbırakanın tasarruf özgürlüğünü kısıtlaması açısından eleştirilmektedir ${ }^{13}$. Hükmün ikinci fikrasında yer alan ehil mirasçının ölüme bağlı tasarruf ile belirlenebilmesine ilişkin düzenleme ise mirasbırakanın son arzularına sayg1 gösterilmesi ilkesi bakımından isabetlidir. Ancak yine aynı ilke gereğince, sulh hakiminin, itiraz üzerine yapacağı değerlendirmenin kapsamı, mirasbırakanın belirlediği mirasçının gerçekten ehil olup olmadığı ile sınırlı olmalıdır.

Mülkiyetin devri için aranan koşulların bulunması durumunda mirasçılar anlaşarak, anlaşamazlarsa mahkeme kararı ile veya mirasbırakanın yapacağı ölüme bağlı tasarruf ile mülkiyetin devri sağlanabilecektir. Mirasbırakanın ölüme bağlı tasarruf ile böyle bir iradede bulunabilmesi ilgili Kanun'da düzenlenmiştir. Bunun yanında tenkis hükümleri saklı kalmak kaydı ile mirasbırakan sağlararası işlemle de bu yöndeki iradesini ortaya koyabilir. Bu durumda mirasbırakanın sağlararası işlemi, koşulları varsa denkleştirmeye tabi olur. Yapılan işlem muvazaalı ise muris muvazaasının söz konusu olup olmayacağı aşağıda ayrıca incelenecektirr ${ }^{14}$.

\footnotetext{
1 ibid 152-153; Paylaşma, ögretide genel olarak tam ve kısmi olarak ayrılmaktadır. Bu konuda bkz Zahit İmre ve Hasan Erman, Miras Hukuku (Der 2018) 466-467; Mustafa Dural ve Turgut Öz, Miras Hukuku (Filiz Kitabevi 2019) N 1946 vd; H Tolunay Ozanemre, Mirasın Paylaşılması (Turhan 2011) 181.

12 Mirasbırakanın tarım arazisini ölüme bağlı tasarruf ile ehil olmadığı sonradan anlaşılan mirasçıya bırakması durumunda ölüme bağlı tasarrufun bu hükmünün kesin hükümsüz olduğu ve bu hükümsüzlüğün kısmi hükümsüzlük olduğu yönünde bkz Hayriye Şen Doğramacı, ‘6537 Sayılı Toprak Koruma ve Arazi Kullanımı Kanununda Değişiklik Yapılması Hakkında Kanunun Mülkiyet Hakkının Sınırlandırılmasına İlișkin Hükümlerinin Değerlendirilmesi' (2017) 13(2) Yeditepe Üniversitesi Hukuk Fakültesi Dergisi 69, 89. Yavuz ve Topuz (n 8) 690'da, yazarlar, TMK 557'de öngörülen sebeplerden biri ile iptal davası açılmadan sulh hâkiminin kendiliğinden mirasbırakanın ölüme bağlı tasarrufunu hükümsüz saymasının miras hukukundaki ilkelerden "mirasbırakanın son arzularına saygı gösterme ilkesine" aykırı düştügünü belirtmekte ve 8/F hükmünü eleştirmektedirler. Aynı yönde bkz Özay (n 11) 167.

13 Bu hüküm ile mirasbırakanın tasarruf özgürlüğünün kısıtlandığı ve tarımsal araziler bakımından paylaştırma kuralı koyma serbestisinin ortadan kalktığı yönünde bkz Bağc1 (n 8) 458.

Mülga TMK 659-668 arası hükümleri, emredici olmadığından mirasbırakan, bu düzenlemeleri ölüme bağlı tasarruf ile aşabiliyordu. Mülga düzenleme döneminde mirasbırakan tarımsal işletmeyi mirasçılardan birine tahsis edebilmekte, mirasçılar arasında taksime ilişkin belirleme yapabilmekteydi. Mirasbırakanın koyduğu taksim kurallarının miras hukuku hükümlerinden önce geldiğine ilişkin İsviçre öğreti ve mahkeme kararları için bkz İmre ve Erman (n 13) 509, n 12.

14 Bkz II/B, III.
} 


\section{B. Mülkiyetin Devri İçin Aranan Koşullar}

\section{Mirasın Açılması}

Tarım arazisinin mülkiyetinin devredilebilmesi için terekenin bulunması ve tarım arazisinin terekenin bir unsuru olması gerekir ${ }^{15}$. TKAKK 8/B/II'de mirasçıların mirasın açılmasından itibaren devir işlemlerini gerçekleştirebilecekleri belirtilmiştir. TMK 575'e göre miras, mirasbırakanın ölümü ile açılır. Diğer bir ifadeyle mirasbırakanın ölümü ile miras kendiliğinden mirasçılara geçer ${ }^{16}$. Ölüm karinesi ${ }^{17}$ ve gaiplik kararı durumları da ölüm gibi mirasın açılmasına neden olur ${ }^{18}$.

6537 sayılı Kanun değişikliğinden önce, özgüleme sisteminde mirasın açılmasının yeterli olmayıp mirasın paylaşılması aşamasına geçilmesi gerektiği ileri sürülmekteydi ${ }^{19}$. Mirasın paylaşılması bakımından sözleşmeden veya kanundan doğan bir takım istisnaların varlı̆ğ halinde ise özgüleme aşamasına geçilememekteydi. 6537 sayılı Kanun değişikliği uyarınca tarım arazilerinin mülkiyetinin devri için mirasın açılması yeterli olduğundan mirasın paylaşılmasına ilişkin kanundan veya sözleşmeden doğan bir engelin bulunması halinde, tarım arazilerinin terekeden ayrı tutularak kanunda belirtilen süre içinde devrinin yapılması gerektĭgi; bu sonucun, kanun hükmünün kamu hukuku ve emredici niteliğinden geldiği belirtilmektedir ${ }^{20}$. Aynı sonuca, TMK 642/3 veya 643 uyarınca mahkeme karariyla mirasın paylaşılmasının ertelenmesi durumlarında da varılmalı ve tarım arazileri tereke dişında tutularak mülkiyetin devri gerçekleştirilmelidir ${ }^{21}$.

Ölüme bağlı tasarrufun bulunması ve bu tasarrufa karşı iptal davası açılması durumunda ise iptal davası sonuçlanmadan iradi devir yapılamayacak, mahkeme kararıla yapılacak devirde de bu durum bekletici mesele yapılacaktır. Zira ölüme bağlı tasarrufun iptalinde görevli mahkeme asliye hukuk mahkemesidir. Tarım arazisinin mülkiyetinin devrine karar verecek hâkim ise sulh hukuk hâkimidir ve iptal davasının sonucu bekletici mesele olacaktır ${ }^{22}$.

15 Özay (n 11) 157; Erdoğan (n 10) 138.

16 Necip Kocayusufpaşaoğlu, Miras Hukuku (Filiz Kitabevi 1987) 519; Rona Serozan ve İlkay Engin, Miras Hukuku ve Uygulama Çalışmaları (Seçkin 2018) §5, N 3, N 4; İmre ve Erman (n 13) 303; Dural ve Öz (n 13) N 1472; Ahmet M Kılıçoğlu, Miras Hukuku (Turhan 2018) 258.

17 Serozan ve Engin (n 18) §5, N 7; Dural ve Öz (n 13) N 1476; Gökhan Antalya ve İpek Sağlam, Miras Hukuku (Legal 2015) 314; Kilıçoğlu, Miras (n 18) 259.

18 Kocayusufpaşaoğlu, Miras Hukuku (n 18) 519, 560; İmre ve Erman (n 13) 303; Antalya ve Sağlam (n 19) 314; Serozan ve Engin (n 18) §5, N 7 ve N 11'de gaiplik kararının ölüm tehlikesinin gerçekleştiği veya son haber alındığı günden başlayarak hüküm doğuracağı, bu nedenle gaibin mirasının bu anda açılmış olacağı belirtilmektedir. Aynı yönde Dural ve Öz (n 13) N 1480.

19 Özay (n 11) 155.

20 ibid 156; Erdoğan (n 10) 139-140.

21 Özay (n 11) 156, n 29'da, TMK 643'te belirtilen cenin sebebiyle erteleme durumunda, ertelemenin en fazla doğuma kadar olacağı ve kanunda belirtilen 1 yıllık sürenin aşılmayacağı, bu nedenle de devir için beklenebileceği belirtilmiştir.

22 ibid 157. Mülga 1086 sayılı HUMK'da sulh hukuk hakiminin asliye hukuk hakiminin kararın beklemesi gerektiğine ilişkin hüküm bulunmaktaydı. 6100 sayılı Kanun'da ise açıkça böyle bir hüküm bulunmamakla birlikte ortaklığın giderilmesi ve paylaştırma davalarında sulh hakiminin bekletici mesele yapması gerektiği belirtilmektedir. Bkz Buket Sevinç Aydın, 'Bekletici Sorun' (2012) Selçuk Üniversitesi Sosyal Bilimler Enstitüsü, Yüksek Lisans Tezi 30 <tez.yok.gov.tr >Erişim Tarihi 27.6.2019. 


\section{Tarım Arazisinin Bulunması}

Kanun'un 8/B hükmünde, tarımsal arazi ve yeter gelirli tarım arazilerinin devredilebileceği belirtilmiştir.

5403 sayılı Kanun'da, TMK'dan farklı olarak tarımsal işletme yerine tarımsal araziden bahsedilmektedir. Tarımsal işletme, toprak, yapı, araç gereç, hayvan ve diğer sermaye unsurlarından oluşan, tarımsal alanda üretimde bulunan ve belirli bir büyüklüğe sahip olan ekonomik bütün olarak tanımlanmaktadır ${ }^{23}$. Öğretide, tarımsal işletme kavramını taşınır, taşınmaz ve sermaye unsurlarını içeren daha geniş bir kavram olarak kabul eden görüşler de bulunmaktadır ${ }^{24} .5403$ sayılı Kanun'da değişiklik yapan 6537 sayılı Kanun'dan önce tarımsal işletmenin tanımı kanunda yer almamaktaydı. Bu nedenle 6537 sayılı Kanun'un tasarı metninde tarımsal işletme tanımı da yer almaktayd ${ }^{25}$. Tasarı metnindeki tanımda, tarımsal işletmenin "arazi" olarak ifade edilmesinin bir hatadan ibaret olduğu söylenmiştir ${ }^{26}$. Tasarı kanunlaşırken tarımsal işletme tanımı çıkartılmış ve mülkiyetin devri sistemi tarım arazisi esas alınarak düzenlenmiştir. Ancak, gerek Kanun'un genel gerekçesinde gerek de madde gerekçelerinde tarımsal işletmeden söz edildiğinden kanun koyucunun tarımsal arazi ifadesiyle yeni bir kurum veya kavram getirmek niyetinde olmadığ 1 da belirtilmiştir ${ }^{27}$. Tarımsal arazinin emek, sermaye ve teşebbüs unsurlarını bünyesinde bulundurmasından dolayı kendisinin de bir tarımsal işletme olduğu da ayrica belirtilmektedir ${ }^{28}$.

Kanun'da tarım arazisi, "Toprak, topografya ve iklimsel özellikleri tarımsal üretim için uygun olup, hâlihazırda tarımsal üretim yapılan veya yapılmaya uygun olan veya imar, ihya, ıslah edilerek tarımsal üretim yapılmaya uygun hale dönüştürülebilen arazi" (3/d) olarak tanımlanmış, mutlak tarım arazisi, özel ürün arazisi, dikili tarım arazisi ve marjinal tarım arazisi tanımlarına ayrıca yer verilmiştir ${ }^{29}$.

6537 sayılı Kanun ile yapılan değişikliklerden biri de asgari tarımsal arazi büyüklüğü ve yeter gelirli tarımsal arazi büyüklüğü kavramlarının kanuna girmiş olmasıdır. 6537 sayılı Kanun ile yapılan değişiklikle tarım arazileri, artık asgari tarım

\footnotetext{
Fikret Eren ve Veysel Başpınar, Toprak Hukuku (Savaş 2017) 164.

Öğreti ve mahkeme kararlarının yaptığı tanımlar için bkz Özay (n 11) 33-37.

25 Tasarının 3. maddesinde " $u$ ) Tarımsal işletme: Üretim faktörleri kullanılarak, bitkisel veya hayvansal üretim yapan ya da üretimlere ilave olarak işleme, depolama ve pazarlamaya yönelik faaliyetlerde bulunan gerçek veya tüzel kişilere ait ekonomik bütünlük arzeden araziler" olarak yer almıştır.

26 Özay (n 11) 36. AYM'nin 5403 sayılı Kanun'un 8/A ve 8/İ maddelerinin iptali için açılan ve ret kararı verilen 30.10.2014 tarih ve 133/165 sayılı kararında da, “...Anılan Kanun'un tanımlar başlıklı 3. maddesinde, yeter gelirli tarımsal arazi büyüklü̈̈̈̈, "bölge farklılıkları göz önünde bulundurularak il ve ilçelerin ekli (1) sayll listede belirlenen yeter gelirli tarımsal arazi büyüklükleri" biçiminde tanımlanmaktadır. Kuralda her ne kadar "tarımsal arazi" kavramı kullanılmış ise de bundan kastedilenin tarımsal işletme olduğu anlaşılmaktadır." ifadesi yer almaktadır.

27 Eren ve Başpınar (n 25) 160.

29 Tarım arazisi nitelendirilmesine bağlı sonuçlar hakkında bkz Melek Bilgin Yüce, '5403 Sayılı Toprak Koruma ve Arazi Kullanımı Kanunu ile Getirilen Kanuni Kısitlamalar’ (2011) 10(2) İKÜHFD 105, 107 vd.
}

28 ibid 160. 
arazisi ve yeter gelirli tarım arazisi olarak belirtilmektedir. 6537 sayılı Kanun ile değişik 5403 sayılı Kanun'un 3. maddesinin h bendi ${ }^{30}$ uyarınca, "asgari tarımsal arazi büyüklüğü: üretim faaliyet ve girdileri rasyonel ve ekonomik olarak kullanıldığ takdirde, bir tarımsal arazide elde edilen verimliliğin, söz konusu tarımsal arazinin daha fazla küçülmesi hâlinde elde edilemeyeceği Bakanlıkça belirlenen en küçük tarımsal parsel büyüklüğünü", 1 bendi' ${ }^{31}$ uyarınca, "Yeter gelirli tarımsal arazi büyüklügü: Bölge farklılıkları göz önünde bulundurularak il ve ilçelerin ekli (1) sayılı listede belirlenen yeter gelirli tarımsal arazi büyüklüklerini” ifade etmektedir.

Yeter gelirli tarımsal arazi büyüklüğü, tarım arazilerinin bölünebileceği en küçük birimi ifade etmektedir ${ }^{32}$. Yeter gelirli tarımsal arazi büyüklüğünün belirlenmesinde alt sınır ise asgari tarımsal arazi büyüklüğüdür. Diğer bir ifadeyle yeter gelirli tarımsal arazi büyüklüğü, asgari tarımsal arazi büyüklüğüne eşit veya ondan fazladır, daha az olamaz. Asgari tarımsal arazi büyüklüğü ülkenin genelinde geçerli alt sınırı oluşturur ve Bakanlıkça belirlenir ${ }^{33}$. Yeterli gelirli tarımsal arazi büyüklükleri ise her bir bölgenin gösterdiği farklılık sebebiyle TKAKK'ya bağlı ekli listede belirlenmiştir ${ }^{34}$.

Mülkiyetin devri sistemine ilişkin düzenleme hükümlerine bakıldığında bazı hükümlerde tarım arazisi ve yeter gelirli tarım arazisi ifadesi kullanılmakta ${ }^{35}$, bazı hükümlerde ise sadece yeter gelirli tarım arazisi ifadesine $\operatorname{rastlanmaktadir}^{36}$. $\mathrm{Bu}$ nedenle öğretide bir görüş, tarımsal arazilerin mülkiyetinin devri koşulları arasında tarımsal arazinin yeter gelirli bir tarım arazisi olmasını da saymıştır ${ }^{37}$. TKAKK 8/B, açıkça, mülkiyetin devrinin hem tarım arazileri hem de yeter gelirli tarım arazileri bakımından söz konusu olabileceğini düzenlediğinden tarımsal arazilerin devrinde yeter gelirli olmanın bir şart olmadığı kanaatindeyiz ${ }^{38}$.

\section{Devir Yapılacak Mirasçının Bulunması}

Kanun'un 8/C maddesi “devir yapılacak mirasçı” başlığını taşımaktadır 39 . Kanun'daki başlığa uygun olması için çalışmada da bu başlık tercih edilmiştir; ancak

30 Değişik: 30/4/2014-6537/3 md.

31 Değişik: 30/4/2014-6537/3 md.

32 Barış Özçelik, '5403 Sayılı Toprak Koruma ve Arazi Kullanımı Kanunu’nda 6537 Sayılı Kanun'la Yapılan Değişiklikler ve Değerlendirilmesi’ (2015) 19(1) Gazi Üniversitesi Hukuk Fakültesi Dergisi 87, 89.

33 TKAKK 8/III uyarınca, "Asgari tarımsal arazi büyüklügü; mutlak tarım arazileri, marjinal tarım arazileri ve özel ürün arazilerinde 2 hektar, dikili tarım arazilerinde 0,5 hektar, örtü altı tarımı yapılan arazilerde 0,3 hektardan küçük belirlenemez. Bakanlık asgari tarımsal arazi büyüklüklerini günün koşullarına göre artırabilir... '

34 Kanunda il ve ilçe bazında detaylı bir liste verilmiştir. Örneğin, Antalya ili Demre ilçesinde sulu arazide 70 dekar (da), kuru arazide 200 da, dikili arazide 10 da yeterli tarımsal arazi iken, Bartın İli Amasra ilçesinde sulu arazide 80 da, kuru arazide 135 da, ekili arazide 10 da yeterli tarımsal arazi olarak kabul edilmiştir.

35 TKAKK $8 / \mathrm{B}, 8 / \mathrm{C}$.

36 TKAKK 8/Ç, 8/E, 8/F, 8/G, 8/Ğ, 8/H, 8/K.

37 Eren ve Başpınar (n 25) 168 vd; Erdoğan (n 10) 141, 142-146.

38 Aynı görüş için bkz Özay (n 11) 157-158; Bağcı (n 8) 74.

39 Bağcı (n 8) 465’te yazar, hükmün içeriğinde mirasçı dışındaki kişilere de devir yapılabileceğinin düzenlenmesi sebebiyle maddenin içeriği ile başlığı arasında uyumsuzluk bulunmasına dikkat çekmiştir. 
devrin mutlaka mirasçıya yapılması şart değildir. Hüküm uyarınca mirasçıların anlaşarak arazinin mülkiyetini üçüncü kişiye devretmesi de mümkündür. Tek bir mirasçının bulunması halinde tereke tümüyle bu mirasçıya geçeceği, hiçbir mirasçının bulunmaması halinde de devlete kalacağı için bu hallerde mülkiyetin devrine ilişkin 5403 sayılı Kanun hükümleri uygulama alanı bulmayacaktır ${ }^{40}$. Mülkiyet kendisine devredilecek mirasçının mirastan feragat, yoksunluk, mirastan çıkarma, mirasın reddi gibi sebeplerle mirasçılık sıfatını kaybetmemiş olması da gerekmektedir ${ }^{41}$.

8/C hükmünün birinci fikrası, mirasçıların anlaşması durumunda yapılacak devrin; ikinci fikrası ise mirasçıların anlaşamaması durumunda içlerinden birinin açacağı dava ile sulh hakiminin karar vereceği devrin koşullarını düzenlemektedir. 8/Ç hükmü ise, tarım arazilerinin 8/B hükmünde belirtilen süreler içinde devredilmemesi durumunda Bakanlık tarafından sulh hukuk hakimi nezdinde açılacak davanın konusu tarım arazisinin ehil mirasçıya, ehil mirasçı olmaması durumunda en fazla teklifi veren istekli mirasçıya devri, aksi hâlde üçüncü kişilere satılmasını içermektedir ${ }^{42}{ }^{43}$.

İlgili Kanun hükmünde mirasçıların anlaşamaması durumunda ehil mirasçıya öncelik tanınacağı belirtilmiş, mirasçıların anlaşması durumu için ise ehil mirasçılık kıstası belirtilmemiştir ${ }^{44}$. Ehil mirasçıya öncelik tanınmasının, TMK 649'da düzenlenen "kanunda aksine bir hüküm bulunmadıkça mirasçılar, paylaşmada terekenin bütün mallarl üzerinde eşit hakka sahiptirler" hükmüne bir istisna getirdiği ifade edilmiştir ${ }^{45}$. Bu istisnanın 5403 sayılı Kanun'un amacına uygun olduğu, ancak sadece mirasçıların anlaşamadığı haller için değil, her türlü devirde esas alınması ve tarım arazilerinde ehil kişilere öncelik tanınması gerektiği düşüncesindeyiz.

\footnotetext{
40 Özay (n 11) 158; Eren ve Başpınar (n 25) 181-182.

${ }^{41}$ Eren ve Başpınar (n 25) 175-176; Şen Doğramacı (n 14) 89-90; İmre ve Erman (n 13) 509.

42 Yavuz ve Topuz (n 8) 685’te yazarlar, Kanun'un 8/C ve 8/Ç hükümlerindeki düzenlemenin Bakanlığa böyle bir yetki verilerek, özel mülkiyete müdahale etmesinin, kamu yararı düşüncesiyle de olsa, aşırı ve bu nedenle Anayasaya aykırı olduğunun ileri sürülebileceğini; bir başvuru olmaksızın, üçüncü kişi durumundaki Bakanlığın açacağı bir dava sonucunda verilecek yargısal bir karar ile tarımsal işletmenin, "ehil" olsa da, bir mirasçıya bırakılmasının ve kendisine malî külfetler de yüklenmesinin veya mirasçıların, tarım arazisinin satış yoluyla üçüncü kişilere devrini kabullenmek zorunda bırakılmasının, mülkiyet hakkının özünü zedelediği görüşünün savunulabileceğini belirtmişlerdir.

Ayrıca mirasçıların, TMK 373 vd maddelerine göre kuracakları aile malları ortaklığına veya kazanç paylı aile malları ortaklığına mülkiyet devrini kararlaştırabilmelerinin yerinde olmadığı ve 8/C maddesinin birinci fikrasının c bendi olmasa da, mirasçıların, Türk Ticaret Kanunu hükümlerine göre bir sermaye şirketi kurmalarının mümkün olduğu yönünde bkz Yavuz ve Topuz (n 8) 685. Hükme ilişkin eleştiriler için ayrıca bkz Özay (n 11) 184 vd.

43 Ankara Bölge Adliye Mahkemesi 15. Hukuk Dairesinin 21.02.2017 tarihli ve 137/102 sayılı bir kararında, ortaklığın giderilmesi istenen bir taşınmaz ile ilgili olmak üzere, taşınmazın tarımsal arazi ve yeterli tarımsal arazi olup olmadığı; mirasçıların ehil olup olmadıkları; birden fazla ehil mirasçı varsa bu mirasçılardan asgari geçimini bu yeterli gelirli tarım arazisinden sağlayan mirasçının bulunup bulunmadığı hususları araştırılmadan ve asgari geçimini yeter tarım arazisinden sağlayan mirasçı bulunmaması halinde mirasçılardan taşınmazı satın almak isteyen varsa bu şahıslardan taşınmazların değeri konusunda teklifler toplanmadan ortaklığın giderilemeyeceği ifade edilmiş; keza, ehil mirasçının tespitinin satış memurluğuna bırakılamayacağına hükmedilmiștir (Kazancı İçtihat Bilgi Bankası).

44 Hükümde mirasçıların anlaşması ihtimalinde sadece tarımsal arazinin bölünmeden devri olgusu üzerinde durulmasının bir eksiklik olduğu ve tarımsal faaliyeti geçim kaynağı yapmak kıstasına göre tespit edilecek ehil mirasçı kavramı ile Kanun'un amacının gerçekleşeceği yönünde bkz Bağcı (n 8) 464.

45 Özçelik (n 34) 95; Eren ve Başpınar (n 25) 155 vd; Şen Doğramacı (n 14) 78.
} 
Mülkiyetin devri, ilk olarak tek bir mirasçıya veya yeter gelirli tarımsal arazi büyüklüklerini karşılaması durumunda birden fazla mirasçıya; ikinci olarak TMK 373 ve devamı hükümlerine göre kurulacak aile ortaklığına veya kazanç paylı aile malları ortaklığına; üçüncü olarak limited şirkete ${ }^{46}$ ve son olarak üçüncü bir kişiye yap1labilecektir.

$\mathrm{Bu}$ noktada öğretide bir yazar, mirasçıların hiçbirinin ya da bazılarının ortak olmadığı bir aile ortaklığgna veya limited şirkete devrin mümkün olması gerektiğini belirtirken ${ }^{47}$, bir diğer yazar ise tarımsal işletmenin birlikte işletilmesinde esas olanın, aile malları ortaklığının elbirliği mülkiyeti şeklinde yönetilmesi olduğunu, ancak bunun aksinin mirasçılar tarafından kararlaştırılabileceğini ${ }^{48}$; ancak mirasçılardan bazılarının pay sahibi olmadığı bir limited şirkete tarımsal arazinin devrinin mümkün olmadığını savunmuştur ${ }^{49}$. Limited şirkete devirden mirasçıların kuracakları limited şirkete tarım arazisini sermaye olarak koymalarının anlaşılması gerektiği, mevcut bir limited şirkete devretmenin üçüncü kişiye devir anlamına geleceği de belirtilmiştir ${ }^{50}$.

Devrin mirasçıya yapılması şart olmamakla birlikte, mirasçıya devir halinde -bize göre mirasçıların kendi aralarında anlaşarak yaptıkları devir de dahil- tarım arazisinin devredildiği mirasçının ehil mirasçı olması gerekir. Kanun, ehil mirasçıya ilişkin kıstasların yönetmelikte belirleneceğini düzenlemiştir. Yönetmeliğin 10. maddesinde ehil mirasçıya ilişkin kıstaslar sayılmıştır ${ }^{51}$. Yönetmeliğe göre ehil mirasçı puanlama sistemine göre belirlenecektir ve yönetmelikte belirlenen puan sistemine göre elli puan ve üstünde alan mirasçılar ehil sayılacaktır. Puanlama sistemine bakıldığında, geçimini tarım arazisinden sağlayanlar, tarım dişı geliri bulunmayanlar, tarımsal arazileri işleme konusunda mesleki bilgi ve beceri sahibi olanlar gibi tarım arazisinin o araziyi işletecek bilgi ve deneyim sahibi kişilere devredilmesinin amaçlandiğ

\footnotetext{
${ }^{46}$ 8/J hükmüne göre, "8/C maddesinin birinci fikrasına göre kurulan aile malları ortakliğının, kazanç paylı aile mallart ortaklı̆̆ının veya limited șirketin; herhangi bir nedenle sona ermesi ve tasfiye olması hâlinde, bu ortakllklara veya limited şirketlere ait tarımsal araziler, yeter gelirli tarımsal arazi büyüklüklerinin altında kalacak şekilde bölünemez”.

47 Özçelik (n 34) 93.

48 Eren ve Başpınar (n 25) 177-178.

49 ibid 179; Serozan ve Engin (n 18) §7, N 59a, 601.

50 Dural ve Öz (n 13) N 2117.

51 “(1) Ehil mirasçının belirlenmesinde aşă̆ıldaki kıstaslar dikkate alınarak yapılan hesaplama sonucunda elli puan ve yukarısına sahip olan mirasçı veya mirasçılar ehil mirasçı olarak kabul edilir. Mirasçılardan;

a) Geçimini mirasa konu tarım arazilerinden sağlayanlara yirmi puan,

b) Tarım dlșl geliri bulunmayanlara on puan,

c) Eşi fiilen tartmsal faaliyette bulunanlara on puan,

c) Tarlmsal arazileri işleyebilecek mesleki bilgi ve beceriye sahip olanlara on puan,

d) Mirasa konu arazilerin bulunduğu ilçe sınırları içinde altı yıla kadar ikamet edenlere beş puan, altı yıl ve daha uzun süre ikamet edenlere on puan,

e) Herhangi bir sosyal güvencesi olmayanlara on puan,

f) Sosyal Güvenlik Kurumu (SGK) kapsamında tarım sigortası olanlara beş puan,

g) Bakanlı̆̆ın mevcut kayıt sistemlerine kayltlllk süreleri altı yıla kadar olanlara beș puan, altı yıl ve daha uzun süre olanlara on puan,

s̆) Tarımsal örgütlere kayttlllı süreleri altı ylla kadar olanlara iki puan, altı yll ve daha uzun süre olanlara beș puan,

h) Tartm alet ve donanımlarına sahip olanlara beș puan,

') Kadın olanlara beş puan verilir".
} 
görülmektedir $^{52}$. İsviçre Federal Mahkemesi de, 62 ve 66 yaşlarındaki iki mirasçıdan tarımsal işletmenin hangisine devredileceği sorununa ilişkin bir kararında, 66 yaşındaki mirasçının hem kendisinin hem de oğlunun çiftçi olarak faaliyet göstermesini bir kıstas olarak almış ve tarımsal varlıkların korunmasının kanunun asıl amaçlarından biri olduğundan hareketle tarımsal işletmenin bu kişiye devredilmesine hükmetmiştir ${ }^{53}$.

Birden fazla ehil mirasçı olması durumunda sulh hakimi, tarım arazisinin TKAKK 8/C/II/b hükmü uyarınca asgari geçimini yeter gelirli tarımsal arazilerden sağlayan mirasçıya $^{54}$, bunun bulunmaması hâlinde bu mirasçılar arasından en yüksek bedeli ${ }^{55}$ teklif edene, ehil mirasçı olmaması hâlinde ise mirasçılar arasından en yüksek bedeli teklif eden mirasçıya devrine karar verir ${ }^{56}$. Arazi bölünmeye rağmen yeter gelirli tarım arazisi büyüklügünü muhafaza edecekse ehil mirasçılar lehine ayrı ayrı da devir gerçekleşebilir (TKAKK 8/III). Birden çok ehil mirasçı bulunması durumunda, 8/F hükmünce ölüme bağlı tasarruf ile de belirleme yapılabilir. Mirasa konu araziyi talep eden mirasçının bulunmaması durumunda hakim, arazinin satışına karar verir, satıştan elde edilen gelir, mirasçılara payları oranında dağıtılır (TKAKK 8/C/II/c).

5403 sayılı Kanun'a göre araziyi devralan mirasçı, miras payına mahsuben tarım arazisini devralmaktadır ${ }^{57}$. Mirasçının devraldığı arazinin değeri, miras payının değerini aşmıyorsa diğer mirasçılara ödeme yapılmaz. Tarım arazisinin değeri, miras payının değerinden fazla ise tarım arazisini devralan, miras payını almamış diğer mirasçılara ödemede bulunur ${ }^{58}$.

Yine 8/C maddesinin son fikrası uyarınca, yeter gelirli tarımsal arazi mülkiyetinin mirasçılardan birine devredilmesinden itibaren yirmi yıl içinde bu arazilerden tamamının veya bir kısmının tarım dışı kullanım nedeniyle değerinde artış meydana gelmesi durumunda; devir tarihindeki arazinin parasal değeri tarım dışı kullanım izni verilen tarihe göre yeniden hesaplanacak ve bulunan değer ile arazinin yeni değeri arasındaki fark, diğer mirasçılara payları oranında ödenecektir ${ }^{59}$.

\footnotetext{
52 Öğretide bir görüş, devir talebinde bulunan mirasçının tarım arazisini işletmeye ehil, yetenekli ve tecrübeli biri olmasının yanında ahlaki özelliklerinin de göz önünde tutulması gerektiğini ileri sürülmüştür. Bkz Eren ve Başpınar (n 25) 182-183; İmre ve Erman (n 13) 509.

53 BGE 107 II 30. Federal Mahkeme bir diğer kararında ise, tarımsal işletmenin 46 yaşında işleri devralmaya niyetli bir oğlu bulanan 75 yaşındaki mirasçıya devredilmesini uygun görmüştür (BGE 111 II 326). Benzer bir karar için bkz BGE 134 III 586.

${ }_{54}$ Bu ifade yerine "geçimini bu işletmeden sağlayan mirasçıya" ifadesinin kullanılabileceği yönünde bkz Yavuz ve Topuz (n 8) 685.

55 Dural ve Öz (n 13) N 2132'de yazarlar bu bedele "alım bedeli" demekte ve bu bedelin diğer mirasçılara miras payları oranında ödeneceğini belirtmektedirler.

56 Ehil mirasçının arazinin mülkiyetinin kendisine devri talebinin kanundan doğan bir alacak hakkı talebi olduğu ve mirasçıların bu devir talebini rıza ile yerine getirmedikleri durumlarda ehil mirasçının TMK 716 uyarınca tescile zorlama davası açabileceği yönünde bkz Şen Doğramacı (n 14) 79.

57 Serozan ve Engin (n 18) §7, N 59a, 603.

58 ibid $\S 7$, N 59a, 603.

59 Bu düzenleme de öğretide tartışmalara neden olmuştur. Yavuz ve Topuz (n 8) 686'da, yazarlar, düzenlemenin mirasçının ilgili mal üzerinde ferdi mülkiyet hakkını elde etmesinden sonra, değer artışının hangi hukuki dayanak ile meşru kılınacağının hukuken izahının güç olduğunu belirtmektedir. Bağcı (n 8) 467, n 30'da ise yazar, ek ödeme yükümlülügünün devir tarihinde tarımsal arazi vasfinda olup daha sonra tarımsal amaç dışında kullanımlar için söz konusu olduğunu ve her ne sebepten olursa olsun tarımsal amaç dışında kullanım sebebi ile ortaya çıkan değer artışının diğer mirasçılara ödenmemesinin devredilen mirasçı lehine dengeyi bozacağı ve haksız kazanç oluşturacağı düşüncesi ile düzenlemeyi uygun bulmaktadır.
} 
Kanun ayrıca, paylaşma davasının devamı süresince tarımsal arazinin yönetimine ilişkin özel bir düzenlemeye de yer vermiştir. Kanun'un $8 / \mathrm{G}$ düzenlemesine göre, ayırt etme gücüne sahip olmayan küçük mirasçı bulunması hâlinde hâkim, yeter gelirli tarımsal arazilerin yönetimini dava sonuçlanana kadar ehil gördüğü mirasçılardan birine veya üçüncü bir kişiye tedbiren verebilir ${ }^{60}$. Hükümde neden sadece yaş küçüklüğü sebebiyle ayırt etme gücüne sahip olmayan mirasçıdan bahsedildiği açık değildir. Örneğin, akıl hastalığı sebebiyle ayırt etme gücüne sahip olmayan bir mirasçı varsa ne olacağı sorusuna öğretide de değinilmiştir ${ }^{61}$. Kanaatimizce, hükmün konulma amacı, tarımsal işletmenin faaliyetlerine devam edebilmesini sağlamak ve tarım arazilerinin yönetimi olduğuna göre, sadece yaş küçüklüğü değil; diğer sebeplerle ayırt etme gücünün bulunmadığı durumlarda da kanundaki önlemin alınabileceği kabul edilmelidir.

\section{Ekonomik Bütünlük}

5403 sayılı Kanun'un 6537 Kanun ile değişik 8/A maddesinde ekonomik bütünlükten bahsedilmekle beraber bir tanım verilmemiştir. 8/A maddesinde, yeter gelirli tarımsal arazi büyüklüklerinin hesaplanmasında, aynı kişiye ait ve Bakanlıkça aralarında ekonomik bütünlük bulunduğu tespit edilen tarım arazilerinin birlikte değerlendirileceğine ilişkin ifade, ekonomik bütünlük koşulunun kapsamını da belirtmektedir. Kanun'a göre ekonomik bütünlük kıstaslarını Gıda, Tarım ve Hayvancılık Bakanlığı belirleyecektir. Bu kıstaslar Tarımsal Arazilerin Devrine İlişkin Yönetmelik’te belirtilmiştir. Bakanlık aynı zamanda, kanun ve yönetmelik hükümlerine ilişkin uygulamalar için Tarım Arazilerinde Mülkiyet Devrine İlişkin Uygulama Talimatı da yayımlamıştır ${ }^{62}$. Tarımsal işletmeler için bahsedilen bütünlük, fiziki veya maddi bir bütünlük olmayıp ekonomik bir bütünlüktür ${ }^{63}$. Tarımsal işletmelerin özgülenmesi sisteminde, işletmeyi meydana getiren unsurların bağımsız olarak ekonomik değeri değil, işletme içerisinde yer alan değerleri esas alınmaktayd ${ }^{64}$. Bu nedenle de, özellikle sermaye içerisinde yer alan ve üretim ya da üretim faaliyeti sonrası için kullanılan binalar ve yapıların ekonomik bütünlük içinde olduğu kabul ediliyordu ${ }^{65}$.

\footnotetext{
60 Yavuz ve Topuz (n 8) 690'da yazarlar, işletmenin tedbiren verilmesi yerine, Türk Medenî Kanununun 427. maddesinin üçüncü bendi gereğince, tarımsal işletmeye bir yönetim kayyımı atanması öngörülmesinin daha yerinde bir düzenleme olabileceğini belirtmişlerdir.

${ }_{61}$ Dural ve Öz (n 13) N 2130. Ayrıca yazarlar böyle bir durumda TMK 589-592 hükümlerindeki koruma önlemlerine başvurulmasında bir engel olmadığını belirtmişlerdir.

62 T.C. Gıda Tarım ve Hayvancılık Bakanlığı Tarım Reformu Genel Müdürlüğü, Tarım Arazilerinde Mülkiyet Devrine İlişkin Uygulama Talimat1, 03.11.2017, Say1: 58776518-010.07.01-E.2768754.

63 Eren ve Başpınar (n 25) 166; Özay (n 11) 86.

64 Özay (n 11) 87.

65 ibid 87-88; Eren ve Başpınar (n 25) 166; İpek Sağlam, 'Tarımsal İşletmelerin Özgülenmesi Sorunu ve Bu Sorunun Tarım Reformu Açısından Değerlendirilmesi' (2010) 16(1-2) MÜHFHAD 201, 204.
} 


\section{Yönetmelik 4/1/d'de, ekonomik bütünlük, mülkiyeti aynı kişiye ait birden fazla tarımsal arazinin tarımsal üretim faaliyetine ekonomik bir değer katacak şekilde birbirine bağımlı olarak işletildiği Bakanlıç̧a tespit edilen arazileri ifade etmektedir. Yönetmelik 7'de ve Talimat birinci bölümde ${ }^{66}$ ekonomik bütünlüğün olup olmadığının}

${ }_{66}$ "Tarımsal arazilerde ekonomik bütünlük, asgari tarımsal arazi büyüklüğü ve yeter gelirli tarımsal arazi büyüklüğü tespiti aşağıdaki kriterlere göre belirlenir. a) Aynı ilçe sınırları içindeki tarım arazilerinin aralarındaki mesafe kuş uçuşu 10 km'den az ve örtü altı tarım arazilerinde 1 dekar, dikili tarım arazilerinde 5 dekar, sulu ve kuru tarım arazilerinde 10 dekar ve üzerinde ise bu araziler arasında ekonomik bütünlük bulunduğu kabul edilir, bu büyüklüklerin altında olan tarım arazileri ekonomik bütünlük arz etmez. b) Mesafe ölçümü, talep konusu tarımsal arazi ile ekonomik bütünlük değerlerine sahip diğer tarım arazileri arasında birbirine en yakın iki nokta arasından yapılır. En az bir noktada birbirleri ile ortak sınırı bulunan tarım arazileri sınırdaş olarak değerlendirilir. Ancak, paylı tarım arazileri diğer tarım arazileri sınırdaş olarak değerlendirilmez ve paylı tarım arazilerindeki paydaşlar sınırdaş araziler için ön alım hakkı kullanamaz. c) Mülkiyeti aynı kişiye ait, sınırdaş olan tarımsal arazilerin toplam büyüklükleri örtü altı tarım arazilerinde 1 dekar, dikili tarım arazilerinde 5 dekar, sulu ve kuru tarım arazilerinde 10 dekar ve üzerinde olması halinde, bu arazilerde ekonomik bütünlük değerlendirmesi yapılır. ç) Paylı tarım arazilerinde kişinin tarım arazisi içindeki pay miktarı dikkate alınarak ekonomik bütünlük değerlendirmesi yapılır. d) Asgari tarımsal arazi büyüklüğ̈̈; mutlak tarım arazileri, marjinal tarım arazileri ve özel ürün arazilerinde 20 dekar, dikili tarım arazilerinde 5 dekar, örtü altı tarım arazilerinde 3 dekardır. e) Yeter gelirli tarımsal arazi büyüklükleri; örtü altı tarım arazilerinde 3 dekar, dikili tarım arazilerinde 10 dekar, kuru ve sulu tarım arazilerinde ise il ve ilçelerin bölge farklılıkları göz önünde bulundurularak 6537 sayılı Kanuna ekli (1) sayll listede belirlenmiştir.f) Yeter gelirli tarımsal arazi büyüklüğü, ekonomik bütünlük oluşturan tarımsal arazilerin toplamı ile bulunur. Malike ait tarımsal arazi veya arazideki hisse alanı kendi başına, yeter gelirli tarımsal arazi büyüklüğünde ve üzerinde ise ekonomik bütünlük arz eder. g) 6537 Sayll Kanunun yayım tarihinden önce elbirliği halinde intikali yapılan tarım arazilerinde, tapu kaydında görülen hisse miktarları yeter gelirli tarımsal arazi büyüklüğ̈̈ hesaplamalarında dikkate alınır. Hisse oranının belirlenemediği durumlarda, ilgili araziye ait veraset ilamındaki yasal hisse oranlarl dikkate alınabilir. Ancak, muris üzerindeki araziler ile Kanunun yayım tarihinden sonra vefat eden kişilerden intikali yapılan elbirliği mülkiyetli araziler yeter gelirli tarımsal arazi büyüklüğü değerlendirmesinde dikkate alınmaz. ğ) Aile Malları Ortaklığl, Kazanç Paylı Aile Malları Ortaklı̆̆l şeklindeki arazilerde yeter gelirli tarımsal arazi büyüklüğü hesaplanmasında ortaklıktaki hisse oranlart dikkate alınarak hesaba a l l $n$ l $r$. h) Adi ortaklık sözleşmesi ve devamında kurulmak istenen elbirliği taleplerinde, pay adedi artmamakla birlikte paydaş adedinin arttı̆̆ kabul edilir. l) Ekonomik bütünlük, yeter gelirli tarımsal arazi büyüklükleri, satış ve miras yolu mülkiyeti devir işlemleri ilçe bazında yapılır. Aynı ilçe sınırları içerisinde olup, ekonomik bütünlük değerlerine sahip ve aralarında $10 \mathrm{~km}$ ve üzeri mesafe bulunan arazi veya arazi gruplarından her grup farklı zamanlarda satılabilir. Gruplardan birinin yeter gelirli tarımsal büyüklügünü sağlaması halinde, diğer gruptaki arazilerin farklı zamanlarda aynen satışları yapılabilir. i) Aynı ilçe sınırları içerisinde bulunan tarım arazilerinin bir kısmı 3083 Sayılı Kanun, bir kısmı da 5403 Sayılı Kanun kapsamında olması durumunda, yeter gelirli tarımsal arazi büyüklüğ̈̈, her iki kanun kapsamında bulunan ve aralarında ekonomik bütünlük oluşturan tarımsal arazilerinin toplamı ile bulunur. j) Tarım arazisi üzerinde kurulmuş bir irtifak hakkı ve üst hakkı bulunuyor ise irtifak hakkı ve üst hakkı verilen alanlar yeter gelirli tarımsal arazi büyüklüğ̈̈ değerlendirmesinde dikkate alınmaz. Farklı vasıflardaki tarım arazilerinin dönüşüm işlemlerinde, değerlendirmesi yapılan büyüklükler arası oranlar kullanılır. k) Ekonomik bütünlüğ̈̈n altındaki aynı parsel içinde veya sınırdaş arazilerde farkl vasıfların alan dönüşümleri için ekonomik bütünlük oranları kullanılır. Bu tür alanların, asgari ve yeter gelirli büyüklük hesaplamalarında ise, ekonomik bütünlük hesaplaması öncesi asgari ve yeter gelirli tarımsal arazi büyüklükleri arasındaki oranlar kullanılarak bulunur. l) Ekonomik bütünlük değerlendirmesi yukarıdaki kriterler doğrultusunda il, ilçe müdürlükleri ve Bakanlık tarafindan yapılır. Topoğrafik koşullar ve kullanım güçlüğ̈̈nden kaynaklanan diğer mücbir nedenlerden dolayı bu kararlara karşı yapılan itirazlar Bakanlıkça değerlendirilerek karara bağlanır. m) Kamu yatırımlarında ve tarım arazilerinin tarım dışı amaçla kullanım taleplerinde, ekonomik bütünlük, asgari tarımsal arazi büyüklüğü ve yeter gelirli tarımsal arazi büyüklüğ̈̈ kriterleri dikkate alınmaz”. 
değerlendirmesinde bazı kıstaslar belirlenmiştir ${ }^{67}$. Yönetmelik ve Talimatın, aynı malike ait sınırdaş arazilere ilişkin ekonomik bütünlük kıstaslarının farklı olduğu, sonraki tarihli Talimat hükmünün, Yönetmelik hükmünü değiştirdiği görülmektedir. Yönetmelik’te yer alan hükmün Talimat ile değiştirilmesinin doğru olmadığı haklı olarak öğretide belirtilmiştir ${ }^{68}$.

Yönetmelik 8 hükmü ${ }^{69}$ de tarım arazilerinin devrini düzenlemiştir. Hükümler incelendiğinde mülkiyeti aynı kişiye ait belli büyüklük ve yakınlıktaki araziler ile sınırdaş arazilerin ekonomik bütünlük teşkil ettiği görülmektedir ${ }^{70}$.

Yönetmelik 7/2’ de ise ekonomik bütünlüğün istisnası olarak mevduat, katılım, kalkınma ve yatırım bankaları, yurtdışında kurulu bu nitelikteki kuruluşların Türkiye'deki şubeleri, finansal holding şirketleri, Finansal Kiralama, Faktoring ve Finansman Şirketleri Kanunu'na tabi finansal kiralama, faktoring ve finansman şirketleri ile tarım kredi kooperatiflerinin farklı kişilerden alacaklarına mahsuben mülkiyetine geçirdikleri tarımsal araziler arasında ekonomik bütünlük bulunmadığ düzenlenmiştir. $\mathrm{Bu}$ kuruluşların, aynı kişilerden elde ettikleri tarımsal arazilerde bu madde hükmüne göre ekonomik bütünlük değerlendirmesi yapılacağı da düzenlenmiştir. Kanunda belirtilen kuralın istisnasının da, yönetmelik yerine yine kanunda düzenlenmesinin daha uygun olacağı öğretide belirtilmiştir ${ }^{71}$.

\footnotetext{
7 "(1) Aynı kişiye ait tarımsal araziler arasındaki ekonomik bütünlük olup olmadı̆̆nın tespiti aşağıdaki kriterlere göre belirlenir:

a) Örtü altı tarım arazilerinde bir dekar, dikili tarım arazilerinde beş dekar, sulu ve kuru tarım arazilerinde on dekarın altında olan tarım arazileri ekonomik bütünlük arz etmez.

b) Aynı kişiye ait sınırdaş olmayan tarım arazilerinin aralarındaki mesafe on km'den az ve örtü altı tarım arazilerinde bir dekar, dikili tarım arazilerinde beș dekar, sulu ve kuru tarım arazilerinde on dekarın üzerinde ise bu araziler arasında ekonomik bütünlük bulunduğu kabul edilir.

c) Mülkiyeti aynı kişiye ait, sınırdaş olan tarımsal arazilerin ekonomik bütünlük teşkil ettiği kabul edilir.

c) Aynı kişiye ait tarımsal arazilerden birinin veya birkaçının paylı olması durumunda kişinin tarım arazisi içindeki pay miktarl dikkate alınarak ekonomik bütünlük değerlendirmesi yapılır.

(2) 19/10/2005 tarihli ve 5411 sayll Bankacllık Kanununa tabi Türkiye'de kurulu mevduat bankalarl, katılım bankalarl, kalkınma ve yatırım bankaları, yurtdışında kurulu bu nitelikteki kuruluşların Türkiye'deki şubeleri, finansal holding şirketleri, 21/11/2012 tarihli ve 6361 sayll Finansal Kiralama, Faktoring ve Finansman Şirketleri Kanununa tabi finansal kiralama, faktoring ve finansman şirketleri ile tarım kredi kooperatiflerinin farklı kişilerden alacaklarına mahsuben mülkiyetine geçirdikleri tarımsal araziler arasında ekonomik bütünlük bulunmaz. Bu kuruluşların, aynı kişilerden elde ettikleri tarımsal arazilerde bu madde hükmüne göre ekonomik bütünlük değerlendirmesi yapılır.

(3) Ekonomik bütünlük değerlendirmesi yukarıdaki kriterler doğrultusunda il veya ilçe müdürlükleri tarafindan yapılır. Topoğrafik koşullar ve kullanım güçlügünden kaynaklanan diğer mücbir nedenlerden dolayı bu kararlara karşı yapılan itirazlar Bakanlıkça değerlendirilerek karara bağlanır."

68 Eren ve Başpınar (n 25) 167.

69 8. maddeye göre, “(1) Tarımsal arazilerin her türlü mülkiyeti devir taleplerinde aşağıdaki işlemler uygulanır.

a) Taşınmaz malikinin aynı ilçe sınırları içinde tarımsal nitelikli tek arazisi olması durumunda bu taşınmazın devri yapilabilir.

b) Taşınmaz malikinin aynı ilçe sınırları içinde birden fazla tarımsal arazisinin bulunması durumunda, bu arazilerin tamamının mülkiyeti devir işlemine konu olması halinde, bu taşınmazların devri yapılabilir.

c) Aynı kişiye ait birden fazla tarımsal arazi olması halinde, 7 nci madde hükümlerine göre yapılan ekonomik bütünlük değerlendirmesi sonrasında tarımsal arazilerin ekonomik bütünlüğe haiz olmayan kısımlarının devrine izin verilebilir.

c) Ekonomik bütünlük arz eden tarımsal arazilerde, yeter gelirli tarımsal arazi büyüklüklerinin üzerinde olan ve yeter gelirli arazi büyüklüklerinin altında ifraz gerektirmeyen arazilerin devrine izin verilir.

d) Paylı tarım arazilerinde, payın tamamının bir veya birden fazla paydaşa devri halinde bu arazilerin devrine izin verilir."

70 Özçelik (n 34) 92.

71 Özay (n 11) 162.
} 
Değinilmesi gereken bir diğer husus da binaların ve yapıların ekonomik bütünlüğe girip girmeyeceği meselesidir. 5403 sayılı Kanun'un 8/E maddesi uyarınca, “Yeter gelirli tarımsal arazi mülkiyeti kendisine devredilen kişi bu araziler için zorunlu olan araç, gereç ve hayvanların mülkiyetinin gerçek değerleri üzerinden kendisine devredilmesini isteyebilir"72. Yine Kanun'un 8/H maddesi uyarnca "yeter gelirli tarımsal arazilere sıkı şekilde bağlı bir yan sınai işletme mevcut ise yan sinai işletme ile yeter gelirli tarımsal arazilerin mülkiyeti bir bütün olarak istemde bulunan ve ehil görülen mirasçıya gerçek değeri üzerinden devredilir". Kanun hükümleri uyarınca mülkiyet devrinin konusu tarım arazileri olup, Kanun'da belirtilen durumlarda taşınır ve yan sınai işletmelerin de devri mümkün olabilecektir. Tarımsal arazinin mülkiyeti kendisine devredilen kişi tarım arazisi için zorunlu olan taşınırlar ve araziye bağlı yan sınai işletmelerin de devrini talep edebilecektir ${ }^{73}$. $O$ halde yan sınaî işletmelerin mülkiyetinin tarımsal araziyle birlikte devredilebilmesi için, işletme ile arazi arasında sıkı bir bağlantının bulunması ve arazi ile işletmenin mülkiyetinin, ehil mirasçı tarafından talep edilmesi şartı aranmıştır. Sıkı bağlantıdan kastın, işletme ile arazi arasındaki ekonomik bütünlük olduğu kabul edilmektedir ${ }^{74}$. Bunun haricinde ekonomik bütünlük, birbirinden bağımsız olsa da birden fazla tarım arazisinin bulunması veya çeşitli tarım arazileri üzerinde payların bulunması durumunda söz konusu olacaktır. Ancak, mirasbırakanın tarım arazisinden uzak ve ayrık bir yerde örneğin bir deposunun bulunması durumunda bu, mülkiyetin devri kapsamına girmeyecektir ${ }^{75}$.

Son olarak, tarım arazileri aynı kişinin mülkiyetinde bulunmalıdır ${ }^{76}$. Tarımsal arazilere ilişkin ekonomik bütünlük mirasbırakanın ölüm anında mevcut olmalıdır ${ }^{77}$.

72 Tarımsal arazinin değerinin bunu alan mirasçının miras payını aşmadığı durumlarda, taşınırların bedeli ödenirken miras payı kadar indirim yapılması konusunda bkz Dural ve Öz (n 13) N 2138.

73 Belirtilen taşınırların TMK 686 anlamında eklenti niteliğinde olduğu, 8/E maddesinin, tarımsal arazinin eklentisi niteliğindeki taşınırların mülkiyetinin devri konusunda ihtilaf çıkması durumunda önem arz edeceği yönünde bkz Özçelik (n 34) 99.

74 Eren ve Başpınar (n 25) 181; Özay (n 11) 190; Uyumaz ve İlhan (n 10) 882; İmre ve Erman (n 13) 511; Dural ve Öz (n 13) N 2140 'ta yazarlar, yan sınai işletmenin aynı taşınmaz üzerinde olup olmaması üzerine bir değerlendirme yapmış ve yan sınai işletmenin bulunduğu taşınmazın terekeye dahil olması şartıyla aynı taşınmaz üzerinde veya başka bir taşınmaz üzerinde olması durumlarında devrin talep edilebileceğini belirtmişlerdir.

75 Özay (n 11) 159.

76 Eren ve Başpınar (n 25)166.

77 ibid (n 25)168; Özay (n 11) 163. 


\section{5403 Sayılı Toprak Koruma ve Arazi Kullanımı Kanunu Karşısında Muris Muvazaası}

\section{A. Genel Olarak Muvazaa ve Özellikle Muris Muvazaası}

Muvazaa (danışıklılık), tarafların iradeleri ile beyanları arasında bilerek uygunsuzluk yaratmaları hali olarak ifade edilir ${ }^{78}$. Muvazaalı (danışıklı) işlem de tarafların yaptıkları hukuki işlemin ${ }^{79}$ hiç hüküm doğurmaması veya görünürdeki işlemden başka bir işlemin hüküm doğurması konusunda anlaşmaları şeklinde tanımlanır ${ }^{80}{ }^{81}$. Öğretide muvazaa, farklı açılardan türlere ayrılmıştır: Taraflar, aralarındaki işlemin hiç hüküm ifade etmeyeceği konusunda anlaşmışlarsa mutlak (basit) muvazaa; gerçek iradelerini saklayarak yaptıkları görünürdeki işlemin arkasındaki gizli işlemin sonuç doğurması konusunda anlaşmışlarsa nisbi (nitelikli) muvazaa söz konusu olur. İşlemin tümünde muvazaa olması, tam muvazaa; bazı hükümlerinin muvazaalı olması ise kısmi muvazaa olarak adlandırılı8² ${ }^{82}$ Yapılan satış sözleşmesinde bedelin, gerçek bedele göre daha düşük ya da yüksek gösterildiği bedelde muvazaa halinde de kısmi muvazaa söz konusudur ${ }^{83}$.

TBK 19 gereğince tarafların gerçek iradeleri dikkate alındığ 1 için, gerçek iradeleri yansıtmayan muvazaalı işlemin kesin hükümsüz olduğu ve bunun sonucu olarak gerek taraflar gerekse menfaati olan üçüncü kişiler tarafindan her zaman $^{84}$ bu

78 Necip Kocayusufpaşaoğlu, Kocayusufpaşaoğlu/Hatemi/Serozan/Arpacı Borçlar Hukuku Genel Bölüm Borçlar Hukukuna Giriş Hukuki İşlem Sözleşme (Filiz Kitabevi 2014) § 35, N 1; Fikret Eren, Borçlar Hukuku Genel Hükümler (Yetkin 2019) N 1087; Safa Reisoğlu, Borçlar Hukuku Genel Hükümler (Beta 2012) 104.

79 Muvazaanın niteliği itibariyle tek taraflı işlemlerde olmayacağı yönünde bkz İsmail Atamulu, Türk Borçlar Hukukunda Muvazaa (Adalet 2017) 35. Belirli bir kimseye yöneltilen, varması gerekli tek taraflı işlemlerde de muvazaa olabileceğ yönünde bkz Kocayusufpaşaoğlu, Borçlar (n 80) § 35, N 7; Eren, Genel Hükümler (n 80) N 1127; Andreas von Tuhr, Borçlar Hukukunun Umumi Kısmı Cilt: 1-2, Çeviren: Cevat Edege (Yargıtay Yayınları 1983) 291.

80 M Kemal Oğuzman, Özer Seliçi ve Saibe Oktay-Özdemir, Eşya Hukuku (Filiz Kitabevi 2019) N 1438; M. Kemal Oğuzman ve Turgut Öz, Borçlar Hukuku Genel Hükümler Cilt-1 (Vedat 2019) N 411; Peter Jäggi, Peter Gauch and Stephan Hartmann, Zürcher Kommentar Obligationenrecht Art. 18 OR, Auslegung Ergänzung und Anpassung der Verträge, Simulation, 4A (Schulthess 2014) N 113; Turhan Esener, Türk Hususi Hukukunda Muvazaalı Muameleler (Ankara Üniversitesi Hukuk Fakültesi Yayınları 1956) 7. Kavram ve tanım hakkında ayrıntılı bilgi için bkz Atamulu (n 81) 19 vd.

81 Görünürdeki işlemin üçüncü kişileri aldatma kastıyla yapılmış olmasının muvazaanın koşulu olup olmadığı tartışmalı olmakla birlikte İsviçre-Türk hukukunda aldatma kastının muvazaanın koşulu olduğu yönünde bkz Jäggi, Gauch and Hartmann (n 82) N 189; Kemal T Gürsoy, Fikret Eren ve Erol Cansel, Türk Eşya Hukuku (Ankara Üniversitesi Hukuk Fakültesi Yayınları 1984) 485; Selin Sert Sütçü, Miras Bırakanın Muvazaalı Hukuki İşlemleri ve Sonuçları (Seçkin 2018) 33; Esener (n 82) 12'de yazar, üçüncü șahısları aldatma kastından, dıșa karșı aldatıcı bir durum yaratmak niyetinin kastedildiğini yoksa muvazaanın her zaman üçüncü kişilere zarar verme niyetiyle yapılan bir işlem olmadığını belirtmiştir. Bununla birlikte üçüncü kişileri aldatma kastından muvazaa anlaşmasının dışında ayrı bir unsur olarak söz etmenin yerinde olmadığı yönünde bkz Nejat Aday, Taşınmaz Mülkiyetinin Naklinde Muvazaa (Kazancı Hukuk Yayınları 1992) 9.

82 A ile B arasında kurulan bir sözleșmenin A ile C arasında kurulmuş gibi gösterilmesi halinde tarafta (kișide) muvazaa şeklinde bir muvazaa türü olduğu yönünde bkz Eren, Genel Hükümler (n 80) N 1104; burada sadece A ile C arasında basit muvazaa olduğu yönünde bkz Oğuzman ve Öz (n 82) N 414.

83 ibid N 413. Ayrıca bkz n 94.

${ }^{84}$ TMK 1023 hükmünün, muvazaa nedeniyle açılacak tapu sicilinin düzeltilmesi davasını da sınırladığını unutmamak gerekir. 
hükümsüzlüğün ileri sürülebileceği kabul edilir ${ }^{85}{ }^{86}$. Ortada gerçeği yansitan bir irade olmadığı için muvazaalı işlemin yok hükmünde olduğunu kabul eden bir görüş de $\operatorname{vardir}^{87}{ }^{88}$.

İşlemin muvazaalı olduğunu iddia eden, iddiasını ispat yükü altındadır. Taşınmaz devri borcu doğuran bir sözleşmede muvazaa iddiasında bulunan taraf, sözleşme şekle tabi olduğundan, iddiasını ancak yazılı delille ispatlayabilir (HMK 201). Üçüncü kişiler, taraflardan farklı olarak, muvazaayı bir ispat şekline tabi olmadan tanıkla dahi ispat edebilirler (HMK 203/d). Öğretide, mirasçıların saklı pay çıkarları açısından üçüncü kişi durumunda oldukları ve muvazaayı tanıkla dahi ispat edebilecekleri, saklı pay dışındaki çıkarları bakımından ise külli halefiyet nedeniyle üçüncü kişi sayılmayıp şekle tabi işlemin muvazaalı olduğunu yazılı delille ispatlayabilecekleri kabul edilir ${ }^{89}$.

Nisbi muvazaa söz konusu olduğunda, muvazaalı işlemin altında gizlenen işlem, gerçek iradeleri yansıttığı için kural olarak geçerlidir (TBK 19/I). Ancak ehliyetsizlik, ahlaka aykırılık gibi muvazaa dişında işlemin kendisinde olan bir geçersizlik nedeni varsa işlem hüküm doğurmaz ${ }^{90}$. Bununla birlikte gizli işlemin geçerliliği bir şekle bağlanmışsa muvazaalı işlem için uyulan şeklin, gizli işlem için aranan şekil şartını gerçekleştirip gerçekleştirmeyeceği tartışmalıdır. Bir görüşe göre muvazaalı işlem için yapılan resmi şekil, gizli işlemin şekil şartını yerine getirmiş sayılır ${ }^{91}$. Hakim görüş ise özellikle taşınmaz mülkiyeti devri borcu doğuran sözleşmelerde, görünürdeki işlemin muvazaa nedeniyle, gizli işlemin de şekle aykırılık nedeniyle

85 Necmeddin Feyzi Feyzioğlu, Borçlar Hukuku Genel Hükümler (İstanbul Üniversitesi Yayınları 1976) 195-196; von Tuhr (n 81) 274-275; Oğuzman ve Öz (n 82) N 415-416; Selahattin Sulhi Tekinay, Sermet Akman, Haluk Burcuoğlu ve Atilla Altop, Tekinay Borçlar Hukuku Genel Hükümler (Filiz Kitabevi 1993) 411-412; Reisoğlu, (n 80) 106; Haluk Nomer, Borçlar Hukuku Genel Hükümler (Beta 2019) N 69 vd; A Barış Özbilen, Sözleşmelerin Şekli ve Şekil Yönünden Hükümsüzlü̆̈̈̈ (On İki Levha 2016) 257.

86 İIK 277 vd hükümleri gereğince alacaklılardan mal kaçırmak amacıyla yapılan tasarruflara karşı açılabilen iptal davası ile muvazaa nedeniyle açılan davayı birbirine karıştırmamak gerekir. Bu konuda bkz Atamulu (n 81) 136 vd. Ayrıca karşılaştırmak için bkz Ahmet M K1lıçoğlu, Borçlar Hukuku Genel Hükümler (Turhan 2019) 242 vd.

87 Kocayusufpaşaoğlu, Borçlar (n 80) §35, N 19; Eren, Genel Hükümler (n 80) N 1105 vd. Yokluk da kesin hükümsüzlük gibi her zaman ve ilgili herkes tarafından ileri sürülebilir ve hâkim tarafından re'sen dikkate alınır. Ancak kesin hükümsüzlükten farklı olarak yokluk halinin ileri sürülmesinde hakkın kötüye kullanılması gündeme gelmez. Yok hükmünde olan bir işlemin tahvil yolu ile başka bir işleme dönüştürülmesi de mümkün olmaz. Öğretide bir diğer görüşe göre ise muvazaalı işlemin geçersizliği klasik anlamda bir kesin hükümsüzlük değildir; sadece tarafların ve üçüncü kişilerin ileri sürebileceği ancak hâkimin re'sen dikkate alamayacağı özel bir geçersizliktir. Bu görüş hakkında bkz Ernst Kramer and Bruno Schmidlin, Berner Kommentar, Allgemeine Einleitung in das schweizerische Obligationenrecht und Kommentar zu Art. 1-18 OR, Schweizerisches Zivilgesetzbuch, Das Obligationenrecht, Allgemeine Bestimmungen, Band/Nr. VI/1/1 (Stämpfli 1986) Art $18 \mathrm{~N} 162$.

88 “...muvazaa ile illetli olarak yapılan temlik yok hükmünde olup (baştan itibaren geçersiz olduğu) bu yokluk bütün mirasçılar bakımından geçerlidir...” (Yargıtay 1 HD, 4564/6700, 22.11.2017, Kazancı İçtihat Bilgi Bankası). Muvazaalı işlemin hiç yapılmamış olduğu yönünde bkz Yargıtay 17 HD, 2013/7947, 2014/15062, 04.11.2014, Kazancı İçtihat Bilgi Bankası.

89 Oğuzman ve Öz (n 82) N 416. Ayrıca bkz II/A.

90 Kocayusufpaşaoğlu, Borçlar (n 80) § 35, N 22; Nomer (n 87) N 69.4; Jäggi, Gauch and Hartmann (n 82) N 156.

${ }_{91}$ Şeref Ertaş, Eşya Hukuku (Fakülteler Barış Kitabevi 2016) N 1275; Selahattin Sulhi Tekinay, Sermet Akman, Haluk Burcuoğlu ve Atilla Altop, Tekinay Eşya Hukuku (Filiz Kitabevi 1989) 439; İlhan E Postacıŏlu 'Namı Müstear ve Muvazaa Meseleleri Hakkında Yeni Görüşler' (1955) A. Samim Gönensay’a Armağan 185. 
geçersiz olduğu yönündedir ${ }^{92}$. Buna göre; gerçekte tarafların iradesinin taşınmaz bağışı, görünürdeki işlemin ise taşınmaz satışı olduğu nisbi muvazaa hallerinde, gerçek iradeleri yansıtmayan taşınmaz satış sözleşmesi muvazaa nedeniyle, gerçek iradeleri yansıtan bağışlama vaadi sözleşmesi ise resmi şekilde yapılmadığ i için geçersizdir. Bu durumda taşınmaz satışı için düzenlenen resmi senet, bağışlama vaadi sözleşmesindeki esaslı unsur olan ivazsızlık halini içermediği, aksine senette satış bedeli gösterildiği için, gizli işlemin şekil şartını sağlamış olmaz ${ }^{93}{ }^{94}$.

Nisbi muvazaa, uygulamada çoğunlukla, mirasbırakan tarafından bir ya da birkaç mirasçı lehine ve diğerlerinin aleyhine, onlardan mal kaçırmak amacıyla, yapılmaktadır. Mirasbırakan genellikle gerçekte ivazsız devrettiği taşınmazları için, tenkis davasını önlemek amacıyla ${ }^{95}$, tapuda satış $^{96}$ ya da ölünceye kadar bakma

92 Yargıtay İBK, 8/7, 7.10.1953; Feyzioğlu (n 87) 204; Gürsoy, Eren ve Cansel (n 83) 485-486; Hasan Erman, Eşya Hukuku (Der 2017) 89; Oğuzman, Seliçi ve Oktay-Özdemir (n 82) 1443; Nomer (n 87) N 69.4; Hüseyin Hatemi ve Emre Gökyayla, Borçlar Hukuku Genel Hükümler (Vedat 2017) § 12, N 4; Kılıçoğlu, Borçlar (n 88) 239-240; Hüseyin Hatemi, Rona Serozan ve Abdülkadir Arpacı, Eşya Hukuku (Filiz Kitabevi 1991) 514-515; Mehmet Ayan, Miras Hukuku (Seçkin 2016) 208; Sert Sütçü (n 83) 68; Özbilen (n 87) 260; Jäggi, Gauch and Hartmann (n 82) N 160.

93 Eren, Genel Hükümler (n 80) N 1119.

94 Kısmi muvazaanın tipik örneği olarak karşımıza çıkan bedelde muvazaa hallerinde de öğretide genel olarak aynı sonuca varılmaktadır (Bedelde muvazaa başta olmak üzere nisbi muvazaa hallerinde, gizli sözleșmedeki șekil eksikliğinin ileri sürülmesinin, özellikle her iki tarafın sözleşmeyi bilerek ifa ettiği halde, hakkın kötüye kullanılması teşkil edebileceği yönünde bkz Kocayusufpaşaoğlu, Borçlar (n 80) § 35, N 24, 25. Bu durumda TMK 2/II'deki koşulların oluşup oluşmadığı gözetilmeksizin şekle aykırılık nedeniyle oluşan kesin hükümsüzlüğün amaca uygun sınırlama yöntemi ile daraltılabileceği yönünde bkz Pakize Ezgi Akbulut, Borçlar Hukukunda Kesin Hükümsüzlük Yaptırımının Amaca Uygun Sinırlama (Teleolojik Redüksiyon) Yöntemi İle Daraltılması (On İki Levha 2016) 148-149). Bununla birlikte vergi mevzuatı (492 sayılı Harçlar Kanunu ve 213 sayılı Vergi Usul Kanunu) uyarınca eksik ödenen harcın gerçek bedel dikkate alınarak cezalı olarak tahsil edilmesinin bedelde muvazaa halinde gizli işlemin geçersiz sayılmasına engel olduğu da ileri sürülmektedir. Bkz Tekinay, Akman, Burcuoğlu ve Altop, Eşya Hukuku (n 93) 669-670. Buna karşılık öğretide haklı olarak ilgili mevzuatın sadece düşük bedelle yapılmış muvazaalı satışlarda değil, düşük bedelli gerçek satışlarda da uygulandığı, vergi hukukunun sözleşmenin geçerli olup olmaması ile değil, tapu harcını doğuran olayın gerçekleşmesi ile ilgilendiği, bu nedenle gerçek bedelden düşük gösterilen taşınmaz satışlarının vergi mevzuatı gereğince geçerli sayılamayacağı da ileri sürülmüştür. Bkz Lale Sirmen, Eşya Hukuku (Yetkin 2018) 337-338. Uygulamada bedelde muvazaaya rastlanılan durumlardan bir diğeri de, önalım hakkı sahibinin bu hakkını kullanmasını engellemek maksadıyla bedelin daha yüksek gösterilmesidir. Resmi senette bedelin düşük gösterilmesinin muvazaa nedeniyle sözleşmeyi geçersiz kılmayacağı, taraf iradelerinin sözleşmenin geçerli olacağı konusunda tam olarak uyuştuğu, bununla birlikte önalım hakkını kullanacak paydaşın bu hakkını düşük bedel üzerinden kullanacağı, ödenecek verginin ise vergi mevzuat gereği rayiç bedel üzerinden tahakkuk ettirileceği; bedelin yüksek gösterilmesi halinde de muvazaa nedeniyle sözleşmenin geçersiz olmayacağı ancak önalım hakkı sahibinin gerçek satış bedelini kanıtlayarak bu bedel üzerinden hakkını kullanabileceği yönünde bkz Ertaş (n 93) N 1276. Ayrıca bkz Murat Aydoğdu, Yasadan ve Sözleşmeden Doğan Önalım Hakkl (Adalet 2013) 41-42.

95 Mirasbırakanın ölümünden önceki bir yıl içinde yaptığı -adet üzerine verdiği hediyeler hariç- bağışlamalar ile bir yıl sınırı olmaksızın saklı pay kurallarını etkisiz kılmak amacıyla yaptığı açık olan kazandırmalar tenkise tabidir (TMK 565/b 3 ve 4).

96 “...Somut olaya gelince, mirasbırakanın, davaya konu bağımsız bölümlerini temlik tarihinde 18 yaşından küçük olan ve alım gücü bulunmayan torunu E. 'ye satış suretiyle temlik ettiği, tanık anlatımlarına göre kira gelirleri bulunan ve hayır işleriyle de uğraşan murisin taşınmaz satmaya ihtiyacının olmadı̆̆ taşınmazların gerçek değerleri ile satış değerleri arasında da fahiş fark bulunduğu anlaşılmaktadır.

Bütün bu somut bulgu ve olgular yukarıda değinilen ilkelerle birlikte değerlendirildiğinde, mirasbırakanın taşınmazlar temlikteki gerçek iradesinin mirasçıdan mal kaçırma amaçlı ve muvazaalı olduğu sonucuna varılmaktadır..." (Yargıtay 1 HD, 2014/4571, 2015/13193, 17.11.2015, Kazancı İçtihat Bilgi Bankası). 
sözleşmesi ${ }^{97}$ yapmaktadir ${ }^{98}$. Bunun birçok nedeni olabilir: Mirasbırakan, kendisi ile yeterince ilgilenmediğini düşündüğü çocuklarına daha az miras payı bırakarak onları cezalandırmak, çocukları arasında cinsiyet ayrımı yaparak, taşınmazlarını sadece kız ya da (genellikle) erkek çocuklarına devretmek, ilk evliliğinden olan çocuklarına daha az miras payı bırakmak veya zayıf durumda olan çocuğunu güçlendirmek isteyebilir ya da yakınlarının baskısı ile muvazaalı işlem yapmış olabilir99.

\section{Yargıtay İçtihadı Birleştirme Büyük Genel Kurulu’nun 1.4.1974 Tarih ve 1/2 Sayılı} Kararı ile mirasçılardan mal kaçırmak amacıyla yapılan muvazaalı taşınmaz satış işlemleri için bazı ilkeler getirilmiştiri ${ }^{100}{ }^{101}$. Bu ilkelerin esas alındığı nisbi muvazaa,

7 “...Miras bırakanın, ölünceye kadar bakıp gözetme karşıllı̆̆ yaptı̆̆ temlikin muvazaa ile illetli olup olmadı̆̆ının belirlenebilmesi içinde, sözleşme tarihinde murisin yaşı, fiziki ve genel sağllk durumu, aile koşulları ve ilişskileri, elinde bulunan mal varlı̆̆ının miktarı, temlik edilen malın, tüm mamelekine oranı, bunun makul karşılanabilecek bir sinırda kalıp kalmadığı gibi bilgi ve olguların göz önünde tutulması gerekir. Somut olayda, yedi parça taşınmaz miras bırakana aitken sağlığında ölünceye kadar bakma sözleşmesi ile davalı oğluna temlik ettiği getirtilen kayıt ve belgelerle sabittir. Tarafların özel durumları, taşınmazların nitelikleri ve değerleri yukarda değinilen ilkelere göre değerlendirildiğinde, miras bırakanın mirastan mal kaçırmak amacıyla muvazaalı temlik yoluna başvurduğu anlaşılmaktadır..." (Yargıtay 1 HD, 2000/14753, 2001/140, 16.1.2001, Kazancı İçtihat Bilgi Bankası).

“...bakıp gözetme koşulu ile yapılan temliki işlemin geçerlilĭgi için sözleşmenin düzenlendiği tarihte bakım alacaklısının özel bakım gereksinimi içerisinde bulunması zorunlu değildir. Bu gereksinmenin sözleşmeden sonra doğması ya da alacaklının ölümüne kadar çok kısa bir süre sürmüş bulunması da sözleşmenin geçerliliğine etkili olamaz. Kural olarak, bu tür sözleşmeye dayalı bir temlikin de muvazaa ile illetli olduğunun ileri sürülmesi her zaman mümkündür. En sade anlatımla muvazaa, irade ile beyan arasında kasten yaratılan aykırılık olarak tanımlanabilir. Böyle bir iddia karşısında, asıl olan tarafların akitteki gerçek ve müşterek amaçlarının saptanmasıdır. (TBK m. 19 (BK m. 18)). Şayet bakım alacaklısının temliki işlemde bakıp gözetilme koşulunun değil de, bir başka amacı gerçekleştirme iradesini taşıdı̆̆ belirlenirse (örneğin mirasçılarından mal kaçırma düşüncesinde ise), bu takdirde akdin ivazlı (bedel karşıllğ̆l) olduğundan söz edilemez; akitte bağış amacının üstün tutulduğu sonucuna varılır. Bu halde de Yargıtay Iç̧tihadı Birleştirme Büyük Genel Kurulu'nun 1.4.1974 gün ve 1/2 Sayılı İçtihadı Birleştirme Kararı olayda, uygulama yeri bulur. Miras bırakanın, ölünceye kadar bakıp gözetme karşıll ̆̆g yaptı̆̆ temlikin muvazaa ile illetli olup olmadığının belirlenebilmesi içinde, sözleşme tarihinde murisin yaşı, fiziki ve genel sağlı durumu, aile koşulları ve ilişkileri, elinde bulunan mal varlı̆̆ının miktarı, temlik edilen malın, tüm mamelekine oranı, bunun makul karşılanabilecek bir sınırda kalıp kalmadığı gibi bilgi ve olguların göz önünde tutulması gerekir. Somut olaya gelince; yukarda da değinildiği üzere Borçlar Kanunu'nun 611. ve takip eden maddelerinde öngörülen ölünceye kadar bakma akitleri talihe bağll akitlerden olup, mutlaka akit tarihinde bakım gibi bir gereksinimin varllğ şart değildir. Diğer taraftan bakım borçlusunun temlik edenin oğlu olması, kendisine bakım koşuluyla temlik yapılmasına mani olmadiğı gibi, aksine yasal bir düzenleme de bulunmamaktadır. Ayrıca, miras birakanın davalı oğlu ile aynı binada altllüstlü oturduğu, ölümünden evvel son 1- 1,5 ayını bakıma muhtaç olarak geçirdiği, dinlenen tanıklar ve özellikle davalı tanığ olarak dinlenen dava dışı să̆ kalan eş ( tarafların annesi )in beyanı ile mirasbırakanın çocukları olan taraflar arasında ayrım yapmadı̆̆ı, davacı kızı ile bir problemi olmadiğı dosya kapsamı ile sabittir. O halde; değinilen bu somut olgular, yukarda değinilen ilkeler çerçevesinde değerlendirildiğinde, mirasbırakanın davaliya ölünceye kadar bakım akti ile yapmış olduğu temlikin mirasçıdan mal kaçırma amacı taşımadığı kabul edilmelidir..." (Yargıtay, 1 HD, 2456/13033, 2.10.2018, Kazancı İçtihat Bilgi Bankası).

98 Dural ve Öz (n 13) N 1142; Serozan ve Engin (n 18) § 3, N 30; Satış ve ölünceye kadar bakma sözleşmeleri kadar sık karşılaşılmasa da trampa (TBK 282 vd) ve ömür boyu gelir sözleşmesi (TBK 607 vd) gibi ivazlı sözleşmeler de mirasçılardan mal kaçırmak amacıyla muvazaalı olarak yapılmaktadır. Bkz Mehmet Beşir Acabey, 'Yargıtay Kararları Işı̆̆ında Muris Muvazaası' iç Tuğçe Tuzcuoğlu ve A Hulki Cihan (edr), Yargıtay Kararları Işı̆ğında Güncel Medeni Hukuk Problemleri Sempozyumu Bildirileri 8-9 Kasim 2018 (On İki Levha 2019) 474.

99 Zeynep Uyar Hatipoğlu, 'Yargıtay İçtihatlarına Göre Muris Muvazaasında Miras Bırakanın Asıl İradesinin Tayini' (2017) 22(36) DÜHFD 109, 111. Bu konuda ayrıntılı bilgi ve Yargıtay kararları için bkz Esra Eviz, Muris Muvazaası (On İki Levha 2019) 64 vd; Sert Sütçü (n 83) 68 vd.

100 “...Bir kimsenin; mirasçısını miras hakkından yoksun etmek amactyla, gerçekte bağışlamak istediği tapu sicilinde kayıtlı taşınmaz malı hakkında Tapu Sicil Memuru önünde iradesini satış doğrultusunda açıklanmış olduğunun gerçekleşmiş bulunması halinde, saklı pay sahibi olsun ya da olmasın miras hakkı çiğnenen tüm mirasçılarının, görünürdeki satış sözleşmesinin Borçlar Kanununun 18. maddesine dayanarak muvazaalı olduğunu ve gizli bağış sözleşmesinin de şekil koşulundan yoksun bulunduğunu ileri sürerek dava açabileceklerine ve bu dava hakkının geçerli sözleşmeler için söz konusu olan Medeni Kanunun 507. ve 603. maddelerinin sağladığı haklara etkili olmayacağına Yargıtay İçtihatları Birleştirme Büyük Genel Kurulunun 1.4.1974 günlü ikinci toplantısında oyçokluğuyla karar verildi...”.

101 Yargıtay, söz konusu içtihadın değiştirilmesi için yapılan başvuru üzerine aldığı sonraki kararında da aynı esaslarda direnmiştir. Bkz Yargıtay İBK, 1/2, 16.3.1990, Kazancı İçtihat Bilgi Bankası. 
Yargıtay uygulamasında ve öğretide "muris muvazaası" olarak adlandırılmaktadır"102. Aslında muris muvazaası ile varılan sonuç, görünürdeki işlemin, gerçek iradeleri yansıtmaması, gizli işlemin ise şekil koşullarını taşımaması nedeniyle geçersiz kabul edilmesi yönünden, genel muvazaa açısından benimsenen çözüm ile uyumludur. Bununla birlikte, Yargıtay kararları ile muris muvazaası için mirastan mal kaçırma kastının aranması ${ }^{103}$, dava hakkının bütün mirasçılara tanınmış olması ve ispat hukuku açısından farklı esaslar getirilmiştir. Buna göre; muris muvazaasından söz edebilmek için öncelikle muvazaa konusu tapuya kayıtlı bir taşınmaz olmalı ${ }^{104}$, mirasbırakan mirasçılardan mal kaçırma amacı ile hareket etmeli, saklı pay sahibi olsun olmasın tüm mirasçılar davacı olabilmeli ${ }^{105}$ ve muvazaa nedeniyle açılan dava, tapu sicilinin düzeltilmesi davası olmalıdır ${ }^{106}$.

Yargıtay kararlarında, mirasbırakanın mal kaçırma amacıyla hareket ettiği durumlarda, mirasçıların, külli halef olarak değil, ihlal edilen miras haklarına dayalı olarak dava açtıkları ve bu nedenle muvazaa iddiasını her türlü delille ispat edebilecekleri ${ }^{107}{ }^{108}$; ayrıca bir mirasçının muvazaa nedeniyle tapu sicilinin düzeltilmesi davası açabilmesi için, mirasbırakanın mal kaçırma kastının o mirasçıya

102 Yargıtay İBK, 4/5, 22.5.1987; Yargıtay 4 HD, 13976/19452, 17.12.2012 (Kazancı İçtihat Bilgi Bankası); Canan Ruhi ve Ahmet Cemal Ruhi, Muris Muvazaası (Seçkin 2017) 15 vd; Erhan Günay, Yargıtay Kararları Eşliğinde Mirastan Mal Kaçırma (Tapulu Taşınmazlarda Muris Muvazaası) (Seçkin 2013) 19; İmre ve Erman (n 13) 295 vd; Antalya ve Sağlam (n 19) 306 vd; Ayan, Miras Hukuku (n 94) 207; Mehmet Ayan, Eşya Hukuku-II- Mülkiyet, (Seçkin 2016) 211-212; Uyar Hatipoğlu (n 101) 110-111; Murat Topuz, 'Yargıtay Kararları Işı̆̆ında Muris Muvazaasının Varlığını Gösteren Emareler' (2016) 15(2-2) İKÜHFD (Prof. Dr. M. İlhan Ulusan’a Armağan Özel Sayı) 709, 710 vd.

103 Genel muvazaada üçüncü kişileri aldatma kastının aranıp aranmayacağı tartışmalı olmakla birlikte muris muvazaası bakımından mirasçılardan mal kaçırma kastının aranacağı hususunda tartı̧̧ma yoktur.

104 Tapusuz taşınmazların taşınır mal niteliğinde olduğu; bu nedenle bağıșlama sözleșmesinin satış sözleșmesinin arkasında gizlenmesi durumunda mülkiyet hakkının devrine ilişkin sözleşmenin herhangi bir şekil şartına bağlı olmadığı ve geçerli olduğu yönünde bkz Günay (n 104) 16-17. “...Dava konusu edilen traktör ve zirai aletler, taşınır mal niteliğindedir. Taşınırların mülkiyetinin nasıl intikal edeceği TMK'nun 763. maddesinde (Eski MK m.687) düzenlenmiştir. Taşınırların elden bağışlanması şekle bağlı olmayıp; bağışlayanın bu şeyi bağışlanana teslimi ile mülkiyet geçer (Eski BK m.237, Yeni BK m.289). Tarafların, iradelerini saklamak suretiyle yaptıklarl görünürdeki sözleşme geçersiz bulunmakla birlikte, gerçekte amaçladıkları sözleşme geçerlidir. Bunun istisnası ise, gerçek sözleşmenin şekle bağlı bulunması halidir. Somut olayda, miras bırakan ile davalı arasındaki gizli sözleşme menkul mal niteliğindeki traktör ve zirai aletlerin bağışlanmasına ilişsindir. Bu gibi sözleşmeler şekil koşuluna bağlı olmadiğından mal elden bağışlanmakla mülkiyeti bağışlanana geçer. Muris muvazaasına iliş̧kin 1.4.1974 gün ve 1/2 sayılı İçtihadı Birleştirme Kararı'nın, ancak tapulu taşınmazlar hakkında ve bununla sınırlı olarak uygulanması söz konusudur. Menkul niteliğindeki traktör ve zirai aletler ile ilgili ve geçerli olan bu temlik işlemine karşı temlik edenin mirasçıları tarafindan (muris muvazaasına dayanılarak) iptal davası açılamaz. Ancak tenkis hükümlerine dayalı olarak talepte bulunulabilir.." (Yargıtay 4 HD, 13976/19452, 17.12.2012, Kazanc1 İçtihat Bilgi Bankası).

105 Aynı yönde bkz Serozan ve Engin (n 18) § 3, N 30, 222. Aksi yönde bkz n 114.

106 Ayrıntılı bilgi için bkz Uyar Hatipoğlu (n 101) 117 vd.

107 Hakim görüş çerçevesinde, görünürdeki işlem muvazaa, gizli işlem şekle aykırılık nedeniyle geçersiz kabul edildiğinde açılan tapu sicilinin düzeltilmesi davasında, ispat açısından saklı payı olmayan mirasçılar için söylenenlerin (külli halef sıfatının), saklı paylı mirasçılar için de geçerli olacağı, buna karşılık diğer görüş çerçevesinde, saklı paylı mirasçı görünürdeki satışın muvazaa nedeniyle geçersiz olduğunu iddia edip gizlenen (ve geçerli kabul edilen) bağışlama sözleşmesinin tenkisini talep ediyorsa kendisine özel olarak tanınan bir hakkı kullandığı için mirasbırakanın muvazaalı işlemi karşısında üçüncü kişi olduğu ve dolayısıyla muvazaayı tanıkla dahi ispat edebileceği yönünde bkz Serozan ve Engin (n 18) § 3, N 32, 223. Yargıtay'ın görüşünün adalet duygusuna ve ahlaki duyarlılığa daha uygun olmasına karşıllı sadece saklı paylı mirasçıları korumanın diğer mirasçıları da mirasbırakanla aynı koşullara bağlamanın kanunun sistemine ve amacına daha uygun olduğu yönünde bkz Dural ve Öz (n 13) 1155. Diğer taraftan tanık beyanının muvazaanın ispatlanmas bakımından yeterli görülmemesi, fiili karineler ile desteklenmesi gerektiği yönünde bkz Sert Sütçü (n 83) 189.

108 Elbirliği halinde malik olan mirasçıların, TMK 640/IV ve 702/IV gereğince tek başlarına ancak tüm mirasçılar için bu davayı açabileceği, mirasçılardan birinin kendi miras payı için tapu sicilinin düzeltilmesi davasını açabileceği yönündeki Yargıtay kararının (HGK, 11.11.2009, 1-458/498) isabetli olmadığı yönünde bkz Nomer (n 87) N 69.5, n 343. 
yönelmesi gerekmeyeceği kabul edilir ${ }^{109}$. Bununla birlikte öğretide saklı pay1 olsun olmasın tüm mirasçıların, muvazaa ve şekle aykırılık nedeniyle açılacak tapu sicilinin düzeltilmesi davasında külli halef sıfatıyla hareket ettikleri; ayrıca mirasbırakanın mal kaçırma amacının sadece saklı pay sahibi mirasçılar açısından önem taşıdığ $1^{110}$, mirasbırakanın tasarruf nisabı çerçevesindeki tasarruf özgürlüğü dikkate alındığında, saklı pay sahibi olmayan mirasçılar açısından mirastan mal kaçırma kastından söz edilmesinin isabetsiz olduğ ${ }^{111}$ belirtilerek söz konusu kararlar eleştirilmiştir ${ }^{12}$. Ayrıca mirasbırakan, sağlığında görünürdeki satış sözleşmesinin muvazaa nedeniyle geçersizliğini tespit ettirdikten sonra gizli işlem bağışlamanın şekle aykırılığını ileri sürerek tapu sicilinin düzeltilmesini TMK 2/II’ye aykırılıktan dolayı sağlayamayacağından, onun külli halefi sıfatıyla hareket eden mirasçılarının ondan ileriye giderek bunu sağlamalarının mümkün olmadığı da ileri sürülmüştür ${ }^{113}$. Buna karşılık, diğer mirasçılardan mal kaçırmak amacıyla mirasbırakanla muvazaalı işlem yapan mirasçıya tapu sicilinin düzeltilmesi davası açıldığında, kötü niyetle hareket eden mirasçının, TMK 2/II'den söz edememesi gerektiği ileri sürülerek Yargıtay'ın vardığı sonucu savunan görüş de mevcuttur ${ }^{114}$.

109 “...miras bırakanın yaptığı muvazaalı sözleşme ile zarar gören bir veya birkaç mirasçı değil, tüm mirasçılar, diğger bir söyleyişle terekedir. Bu itibarla belirli bir mirasçıdan değil, tüm mirasçılardan (terekeden) mal kaçırmak söz konusudur. Bu nedenle uygulamada miras bırakanın hangi mirasçıdan mal kaçırmak amacı taşıdığı değil mirastan (terekeden) mal kaçırmak kastıyla hareket edip etmediği araştırılmaktadır..." Bkz 1 HD 1995/6459 - 8763 sayılı ve 13.6.1995 tarihli Yargıtay kararı ve bu kararda direnilmesi üzerine verilen Y HGK, 1-440/638, 25.9.1996, Kazancı İçtihat Bilgi Bankası.

110 M Kemal Oğuzman, Miras Hukuku (Filiz Kitabevi 1995) 227.

111 Necip Kocayusufpaşaoğlu, Miras Hukuku Ek Kitap (Filiz Kitabevi 1992) 27-28. Saklı pay sahibi mirasçıların muris muvazaasını ileri sürebilecekleri, saklı pay sahibi olmayan mirasçıların ise ileri süremeyecekleri yönünde bkz Hüseyin Hatemi, Miras Hukuku (On İki Levha 2018) § 4, N 40. Buna karşılık muris muvazaasında, mirasbırakanın tasarrufunun saklı paydan yoksun bırakmaya değil miras payından yoksun bırakmaya yönelik olduğu, mirasbırakanın tasarruflarına karşı mirasçıların, saklı pay dışında da korunması gereken menfaatleri olduğu yönünde bkz Antalya ve Sağlam (n 19) 310-311.

112 Mirastan mal kaçırma kavramının yasal dayanağı olmadığı, mirasbırakanın tasarruf özgürlüğünün saklı pay ve tenkis hükümleri ile sınırlandığı, bunların dışında bir sınırlandırma bulunmadığı yönünde bkz Aydın Aybay, Miras Hukuku (Maltepe Üniversitesi Hukuk Fakültesi Yayınları 2003) 70. İlgili İçtihadı Birleştirme Kararının miras hukuku hükümlerine açıç̧a aykırı olduğu yönünde bkz İbrahim Kaplan, 'Muris Muvazaası' (2016) 15(1) İKÜHFD (Prof. Dr. Turhan ESENER'e Armağan) 349, 363. Saklı pay sahibi olan olmayan tüm mirasçıların miras hukuku hükümleri ile yeterince korunduğu, bunun ötesinde muris muvazaası ile korunmalarına gerek olmadığı, bu kurumun artık miladını doldurduğu yönünde bkz Acabey (n 100) 487.

113 Kocayusufpaşaoğlu, Ek Kitap (n 113) 29-30. Benzer şekilde; muris muvazaasında mirasçıyı zarara soktuğu iddia edilen sözleşmenin görünürdeki işlem değil, şekle aykırılıktan geçersiz olan gizli bağışlama olduğu, ayrıca şekle aykırılığın yaptırımının kendine özgü bir geçersizlik olduğu ve sadece taraflarca ileri sürülebildiği, saklı pay sahibi olmayan mirasçıların taraf kavramı içinde yer aldığı, ifa edilen sözleşmede şekle aykırılığı ileri sürmenin hakkın kötüye kullanılması teşkil edebileceği, dolayısıyla saklı payı olmayan mirasçılar ile saklı paylı mirasçıların saklı pay dışındaki miras payları açısından da şekle aykırılığın ileri sürülmesinin hakkın kötüye kullanılması yasağına aykırı olabileceği, diğer taraftan saklı paylı mirasçıların saklı payları oranında şekle aykırılı̆̆ ileri sürmelerinin her zaman mümkün olduğu, bu nedenlerle ilgili Yargıtay İçtihadı Birleştirme Kararının eleştirilebileceği yönünde bkz Eren, Genel Hükümler (n 80) N 1123.

114 İsmet Sungurbey, 'Mirasbırakanın Muvazaası Durumuna İlişkin Yargıtay’ın 1.4.1974 Gün 1/2 Sayılı Doğru İçtihadı Birleştirme Kararı Değiştirilemez' (1994) 6 Medeni Hukuk Sorunları 7, 10 vd. 
Mirasbırakanın muvazaalı işlemi yaptığı tarihte, mal kaçırmak isteyebileceği bir mirasçısı yoksa, sonradan ortaya çıkan mirasçıların muris muvazaasını ileri süremeyeceği, buna karşılık işlem yapıldığı sırada böyle bir mirasçısı varsa, işlem tarihinden sonra mirasçı olanların da muris muvazaasını ileri sürebilecekleri kabul edilir ${ }^{115}$.

Öğretide, muvazaalı işlemin altındaki gizli işlem şekle aykırılık nedeniyle geçersiz kabul edildiğinde, muvazaalı satışın konusu olan taşınmaz, mirasbırakanın malvarlığından çıkmış olmayacağından ${ }^{116}$, tenkis davası da açmaya gerek kalmayacağı; tapu sicilinin düzeltilmesi davası açılmasının yeterli olacağ ${ }_{1}^{117}$ ve bu davanın saklı pay sahibi olsun olmasın tüm mirasçılar tarafından açılabileceği kabul edilir ${ }^{118}$. Bununla birlikte 22.5.1987 tarihli 4/5 sayılı Yargıtay İçtihadı Birleştirme Kararı ile saklı pay sahibi mirasçıların tenkis davası yanında kademeli olarak muvazaa nedeniyle tapu sicilinin düzeltilmesi davası (TMK 1025) açabilecekleri kabul edilmiştir ${ }^{119}{ }^{120}$. Öğretide, 1974 tarihli İçtihadı Birleştirme Kararına olduğu gibi, bu karara da tümüyle

115 Acabey (n 100) 466-477; İhsan Özmen ve Erslan Özkaya, Muvazaa Davalart (Adalet 1993) 167.

..Her ne kadar, muvazaalı sözleşme yapıldığı sırada miras bırakanın sözleşme dışında kalan bir mirasçısının bulunmaması halinde mirasçıdan mal kaçırma kastının varlığından söz edilemezse de, başka bir mirasçının veya mirasçıların bulunması, mal kaçırma kastını oluşturacă̆ından muvazaalı sözleşmenin yapıldı ̆̆ tarihte mirasçı durumunda olmayan ancak sonradan mirasçılık hakkını kazanan herkesin muris muvazaasına dayanarak sözleşmenin geçersizliğini ileri sürerek tapu iptali ve tescil davası açabilme hakkı bulunduğunun kabulü gerekir. Kuşkusuz bașka bir mirasçının muvazaa nedeni ile açtığı iptal ve tescil davası sonunda, miras bırakan adına döndürülen taşınmazdan, sözleşme tarihinde mirasçı olmayıp da, miras bırakanın ölüm tarihinde mirasçılık sıfatını kazanan kişi pay alabilmektedir. Başka bir mirasçının açtığ dava sonunda terekeye döndürülen bir taşınmazdan pay alan kişiye muvazaalı sözleşmenin yapıldı̆̆ı sırada mirasçı bulunmadığından daha sonra mirasçılık sıfatını kazandı̆̆ından söz edilerek dava hakkı tanınmaması bu yöndeki uygulamaya, muvazaa kurallarına ve Medeni Kanunun mirasçılığa ilişkin buyurucu nitelikteki hükümlerine ters düşer. Bunun yanında uygulamada bir kişinin muhtemel mirasçısından mal kaçırmak kastıyla muvazaalı sözleşme yaptığı sıkça rastlanan bir husustur. Önemli olan davacının sözleşme tarihinde değil, mirasın açılma tarihinde mirasçı olmasıdır.

Somut olayda davacı taşınmazın davalıya temliki tarihinde mirasçı değilse de, daha sonra miras bırakanın evlat edinmesi ile mirasçı durumuna gelmiş, ölüm tarihinde mirasçılık sıfatını yitirmemiştir. Miras bırakanın sözleşme tarihinde kendilerinden mal kaçırmak istediği başka mirasçıları da bulunmaktadır.

Hal böyle olunca, açılklanan ilkelere göre, davacının muris muvazaasına dayanarak dava açma hakkı bulunduğundan, işin esasına girilmesi, tarafların temlikin muvazaalı yapılıp yapılmadiğı yönünde, tüm delillerinin toplanması, sonucuna göre bir karar verilmesi gerekirken, yanılgılı değerlendirme ile sözleşmenin yapıldı̆̆ sırada, davacının mirasçı bulunmadı̆̆ından söz edilerek davanın reddine karar verilmesi doğru değildir... ) gerekçesiyle bozularak dosya yerine geri çevrilmekle yeniden yapılan yargllama sonunda; mahkemece önceki kararda direnilmiştir.." (Yargıtay 1 HD, 1995/6459 - 8763, 13.6.1995, Kazancı İçtihat Bilgi Bankası). Ayrıca bkz Yargıtay HGK, 1-596/737, 6.11.1996, Kazanc1 İçtihat Bilgi Bankasi.

116 “....muvazaalı temlike konu taşınmazın murisin terekesinde kalacağı, murisin ölümü ile de tüm mirasçıların taşınmazda mirastan kaynaklanan hak sahibi olacakları... Açıktır..” (Yargıtay 1 HD, 4564/6700, 22.11.2017, Kazancı İçtihat Bilgi Bankası).

117 Serozan ve Engin (n 18) § 3, N 30, 222.

118 Oğuzman, Miras (n 112) 225; M Kemal Oğuzman, 'Miras Bırakanın Gayrimenkule İlişkin Muvazaalı İşlemleri Bakımından Tenkis Davası ve Tapu Kaydının Tashihi Davası’ (1990) Prof. Dr. İlhan E. Postacıŏglu’na Armağan 187, 189.

119 “....Miras bırakanın yaptığı temliki tasarruflardan zarar gören mirasçıların tenkis davası ile birlikte kademeli olarak veya tenkis davası açtıktan sonra ayrı bir dilekçe ile Borçlar Kanununun 18. maddesine, dayalı muvazaa nedeniyle iptal-tescil davası da açabileceklerine karar verilmiştir.” (Yargitay İBK, 4/5, 22.5.1987, Kazancı İçtihat Bilgi Bankası). “..Hal böyle olunca; davacının öncelikli talebi olan pay oranında tapu iptal ve tescil isteği yönünden değerlendirme yapılarak evvela bu talep konusunda bir karar verilmesi; eğer muvazaa iddiasının reddi gerektiği kanaatine varllırsa bu durumda terditli olarak talep edilen tenkis isteği yönünden değerlendirme yapılması gerekirken yazılı şekilde karar verilmesi hatalı olmuştur.” (Yargıtay 1 HD, 72/4102, 21.3.2013, Kazancı İçtihat Bilgi Bankası). Tenkis davası açılıp sonuçlandıktan sonra, söz konusu İçtihadı Birleştirme Kararının uygulanmayacağı yönünde bkz Yargıtay 1 HD, 5687/6367, 18.5.2000, Kazancı İçtihat Bilgi Bankası. Kararın eleştirisi için ve saklı paylı mirasçıların tenkis davası açmalarının sonradan muvazaaya dayalı olarak dava açmalarına engel olmayacağı yönünde bkz Sezer Çabri, Miras Hukuku Şerhi C-I (On İki Levha 2018) N 1536.

120 Ayrıca tenkis talebiyle açılan davanın ıslah yoluyla muvazaa davasına dönüştürülebileceği yönünde bkz Yargıtay 2 HD, 4944/8237, 22.6.2004, Kazancı İçtihat Bilgi Bankası. Muvazaa nedeniyle açılan yolsuz tescilin düzeltilmesi davasının da ıslah ile tenkis davasına dönüştürülebileceği ancak bu halde tenkis davası için aranan süreye dikkat edilmesi gerektiği yönünde bkz Sert Sütçü (n 83) 180. 
karşı çıkanların olduğu ${ }^{121}$ ve özellikle önce tenkise sonra muvazaaya dayanarak terditli dava açılması yönünden kararın eleştirildiği görülmektedir ${ }^{122}$. Diğer taraftan muvazaa nedeniyle geçersiz olan satış sözleşmesinin bağış sözleşmesinin şeklini karşıladığını ve gizli işlemin de geçerli olduğunu kabul eden görüş çerçevesinde, muvazaalı satışın hükümsüzlügünü tespit ettiren saklı paylı mirasçıların, geçerli olan bağışlamanın tenkisini dava edebilecekleri de kabul edilir ${ }^{123}$.

Mirasbırakanın mal kaçırma kastının olup olmadığının, diğer bir ifadeyle muvazaalı işlemi yapmaya yönelik iradesinin tespitinde Yargıtay, somut olaya göre, ülkenin veya bölgenin geleneklerini, toplumsal eğilimi, olayların olağan akışını, mirasbırakanın haklı ve makul bir nedeninin olup olmadığını, davalının satın alma gücünü, taraflar ile mirasbırakan arasındaki ilişkiyi, satış bedeli ile sözleşme tarihindeki gerçek değer arasındaki farkı dikkate alır ${ }^{124}{ }^{125}$.

Muris muvazaasında mirasçılardan mal kaçırma kastının bir unsur olarak aranması nedeniyle mirasbırakanın paylaştırma amacı ile yaptığı işlemlerde muvazaa hükümlerinin uygulanmayacağı Yargıtay tarafindan kabul edilmektedir ${ }^{126}$. Aynı şekilde öğretide de mirasbırakanın sağlığında paylaştırma kastı ile yaptığı satışlarda, mal kaçırma kastı olmayacağı ve dolayısıyla muris muvazaasından söz edilemeyeceği kabul edilmektedir ${ }^{127}{ }_{-}^{128}$.

21 Resmi şekildeki klasik hükümsüzlük görüşünün miras hukukuna kaydırılarak saklı payı ihlal edilmemiş olan mirasçıya geçersizlik davası açma hakkını tanıyan 1.4.1974 tarihli İBK ve onun daha ağırlaştırılmış şekli 22.5 .1987 tarihli İBK ile Türk-İsviçre Miras Hukukunun benimsediği esaslara ve Türk toplumunun ihtiyaçlarına aykırı bir çözümün ortaya çıktığı; mirasçının ancak tenkis davası açabileceği, hukuki menfaati ihlal edilmiş üçüncü kişi durumunda olmadığı için muvazaa veya şekil noksanlığı sebeplerine dayanarak dava açamayacağı yönünde bkz Yaşar Karayalçın, 'Mirasçının Muvazaa Nedeniyle İptal Davası Açma Hakkı Var Mıdır? (1.10.1953, 11.4.1974 ve 22.6.1987 Tarihli İçtihadı Birleştirme Kararları)’ (1989) Yasa Dergisi 323, 337; Yaşar Karayalçın, Mirasbırakanın Muvazaası Mı? Tasarruf Özgürlüğü ve Saklı Payın Korunması Mi? Bir Tartışma (Turhan 2000) 15.

122 Önce tenkis talep ederek sadece saklı payını geri almaya razı olan mirasçısının, sonrasında muvazaa nedeniyle işlemin tümüyle geçersizliğini ileri sürememesi gerektiği, bu durumda ancak muvazaa gerekçesiyle tüm mülkiyet hakkının korunması, bu kabul edilmediğinde sadece saklı payın tenkisinin istenmesi şeklinde bir sıra takip edilebileceği yönünde bkz Dural ve Öz (n 13) N 1151. İçtihadı Birleştirme Kararındaki sıranın olsa olsa önce muvazaa nedeniyle görünürdeki işlemin hükümsüzlüğü tespit edildikten sonra gizli işlemin şekle aykırılığı nedeniyle tapu sicilinin düzeltilmesi; gizli işlemin geçersizliği herhangi bir şekilde ileri sürülemiyorsa tenkisin talep edilmesi şeklinde olabileceği yönünde bkz Kocayusufpaşaoğlu, Ek Kitap (n 113) 26. Diğer taraftan aslında mirasçının münhasıran muvazaa davası ile de sonuç almasının mümkün olmayacağı yönünde bkz Kocayusufpaşaoğlu, Ek Kitap (n 113) 29-30.

123 Serozan ve Engin (n 18) § 3, N 30. Bu şekilde saklı paylı mirasçının tenkis davası açmasını önlemek isteyen mirasbırakanın amacına ulaşmasının engellenmiş olduğu, böyle bir muvazaaya başvurulmuş olmasının saklı payı etkisiz kılma kastını ispatlamaya yettiği, bu nedenle açılacak tenkis davasının TMK 565 b. 4'e tabi olacağı ve bir yıllık süre sınırı olmadan dava açılabileceği yönünde bkz Serozan ve Engin (n 18) §3 N 30, n 30.

124 “...ülke ve yörenin gelenek ve görenekleri, toplumsal eğilimleri, olayların olağan akışı, miras bırakanın sözleşmeyi yapmakta haklı bulunup bulunmadı ğ , davalı yanın alış gücünün olup olmadığl, satış bedeli ile sözleşme tarihindeki gerçek değer arasındaki fark, taraflar ile miras bırakan arasındaki beşeri ilişki gibi olgulardan yararlanılmasında zorunluluk vardır..." (Yargıtay 1 HD, 5420/8997, 14.9.2004, Kazancı İçtihat Bilgi Bankası).

125 Mal kaçırma amacıyla yapılan muvazaalı devir, mirasçılar dışında üçüncü bir kişiye de yapılmış olabilir. Aradaki anlaşma gereği üçüncü kişi, mirasbırakandan devraldığı taşınmazı sonradan onun arzu ettiği bir mirasçıya devredebilir. Bkz Uyar Hatipoğlu (n 101) 119; Sert Sütçü (n 83) 106.

126 Yargitay HGK, 1-295/333, 16.6.2010; Yargitay 1 HD, 4662/8144, 28.6.2012; Yargitay 1 HD, 2014/14650, 2016/3057, 15.3.2016; Yargıtay 1 HD, 2018/2238, 2019/2654, 15.4.2019 (Kazancı İçtihat Bilgi Bankası). Bu durumda denkleştirme hükümlerinin (TMK 669 vd) uygulanması gerektiği yönünde bkz Acabey (n 100) 484.

127 İmre ve Erman (n 13) 297; Uyar Hatipoğlu (n 101) 25-126; Eviz (n 101) 62. Mirasbırakanın mal kaçırma kastı olmadan, sağlığında paylaştırma amacıyla yaptığı muvazaalı işlemlerde, gizli işlemin şekle aykırılığı nedeniyle tapu sicilinin düzeltilmesi yoluna gidilmemesi gerektiği, aksi takdirde esasın haklı gerekçe olmadan şekle feda edilmiş olacağı yönünde bkz İmre ve Erman (n 13) 297.

128 Yapılan kazandırmaların değerlerinin birbiriyle uyumlu olduğu hallerde adil ve usul ekonomisine uygun görünen bu çözümün sağlam dayanağı olmadığ 
Mirasbırakanın, bir mirasçısının üçüncü kişiden satın aldığı taşınmazın bedelini ödediği (gizli bağış olarak nitelendirilen) durumda muris muvazaası olmadığı ${ }^{129}$, tenkis ${ }^{130}$ ve denkleştirme hükümlerine başvurulabileceği kabul edilir ${ }^{131}$.

Yargıtay ve öğretideki hakim görüşten farklı olarak, muris muvazaası olarak kabul edilen hallerde, aslında muvazaa değil kanuna karşı hilenin ${ }^{132}$ söz konusu olduğunu ileri süren bir görüş de vardır. Bu görüşe göre; kanuna karşı hilenin yaptırımı iptal değil, tarafların ulaşmak istediği hukuki sonucun önlenmesi olduğu için ve taraflar da burada tenkis davasını önlemek istediklerinden buradaki işlemin yaptırımı da hükümsüzlük değil, saklı paylı mirasçıların tenkis davası açabilmeleri olmalıdır ${ }^{133}$.

\section{B. Tarım Arazilerinin Devrinde Muris Muvazaası}

Uygulamaya baktığımızda mirasbırakanın yaptığı muvazaalı işlemlerin büyük bir kısmında, mirasçılardan mal kaçırma kastıyla hareket edilmekte, yukarıda da bahsedildiği üzere çeşitli nedenlerle mirasçılar arasında ayrım yapılmaktadır ve bu ayrımın hukuki sonuçlarından, özellikle de tenkis hükümlerinden kaçınmak amaçlanmaktadır. Diğer taraftan bazı hallerde mirasbırakanın mal kaçırma kastı olmamakta, hatta mirasbırakan tapu memurunun yanlış yönlendirmesi sonucu böyle bir işlem yapabilmektedir. Örneğin, mirasbırakan aslında kendisine bakmakta olan ve ölene kadar da bakmayı vaat eden alt soyuna, bu emeğinin karşılığı olarak bir taşınmazını devretmek için tapu müdürlüğüne gittiğinde, bu iradesini açıklamasına rağmen tapu memuru ölünceye kadar bakma sözleşmesi düzenlemek yerine satış sözleşmesi düzenleyerek bu konuda farkındalığg olmayan mirasbırakanın muvazaalı işlem yapmasına vesile olabilmektedir ${ }^{134}$. Hatta bu halde mirasbirakanın üçüncü kişileri aldatma kastı olmadığından yola çıkarak ortada genel anlamda muvazaalı bir işlemin olmadığ 1 da söylenebilir ${ }^{135}$.

\footnotetext{
129 Atamulu (n 81) 41; Oğuzman, Seliçi ve Oktay-Özdemir (n 82) N 1441, n 397; Sert Sütçü (n 83) 102. "01.04.1974 tarihli ve 1/2 sayıl İçtihadı Birleştirme Kararı konusu ve sonuç bölümü itibariyle, mirasbırakanın kendi üzerindeki tapulu taşınmazlar yönünden yaptığı temliki işlemler için bağlayıcıdır. Somut olayda olduğu gibi bedeli ödenerek "gizli bağış" şeklinde gerçekleştirilen işlemler hakkında anılan Yargıtay İçtihadı Birleştirme Kararının doğrudan bağlayıcı olma niteliği yoktur. Bunun yanı sıra, karara, yorum yoluyla gizli bağls iddialarına yönelik olarak uygulama olanağl sağlanamayacağl, Hukuk Genel Kurulunun 30.12.1992 tarihli 586/782 sayll,; 21.09.1994 tarihli ve 248/538 sayll,; 21.12 .1994 tarihli ve 667/856 sayll,; 11.10.1995 tarihli ve 1995/1-608 sayll kararlartnda belirtilmiş; Dairenin yargısal uygulaması bu doğrultuda kararlılık kazanmıştır." (Yargıtay 1 HD, 2014/1718, 2015/22, 12.1.2015, Kazancı İçtihat Bilgi Bankası).

130 Ayan, Eşya (n 104) 212; Nomer (n 87) N 69.8; Eviz (n 101) 104.

131 Ayrıntılı bilgi için bkz Emrehan İnal, 'Denkleștirme ve Tenkis Davalarında Parası Miras Bırakan Tarafından Ödenerek Mirasçılardan Biri Adına Alınan Taşınmazların Durumu’ (2007) 65(2) IÜHHFM 277 vd.

132 Kanuna karşı hile hakkında bkz M Kemal Oğuzman ve Nami Barlas, Medeni Hukuk (Vedat 2019) N 906 vd; Hamide Topçuoğlu, Kanuna Karşı Hile (Kanundan Kaçınma Yolları) (Selüloz 1950) 7 vd.

133 Ali Naim İnan, Seref Ertas ve Hakan Albas, Türk Medeni Hukuku Miras Hukuku (Seçkin 2019) N 1137. Yazarlara göre ayrıca burada hâkim görüşün aksine bir şekil eksikliği de yoktur. Taşınmaz bağış sözleşmesi, resmi şekilde yapılan taşınmaz satış sözleşmesinin içinde gerçekleşmiştir. Her iki sözleşmenin de amacı taşınmaz devri olduğu için burada tahvil kurumunun tipik bir uygulaması söz konusudur. Bkz N 1137, 1373. Burada yazarların tahvile gitmesi eleştiriye açıktır.

134 Yargıtay, taraflar arasında yapılmış ölünceye kadar bakma sözleşmesi olmamasına rağmen, yapılan satış sözleşmesinin karşılığının emek de olabileceğinden yola çıkarak, sağlığında kendisine baktı̆̆ı tespit edilen mirasbırakanın gelinine yapılan tașınmaz satısı ișleminde, mirastan mal kaçırma kastı olmadığı sonucuna varmıstır. Bkz Yargıtay 1 HD, 3636/13452, 15.10.2018, Kazancı İçtihat Bilgi Bankası. Bununla birlikte satış bedelinin mutlaka para olarak belirlenmesi gerektiğ yönünde bkz Fikret Eren, Borçlar Hukuku Özel Hükümler (Yetkin 2017) 36; Haluk Tandoğan, Borçlar Hukuku Özel Borç Iliş̧kileri C.I/1 (Vedat 2008) 84 .

135 Bkz II/A.
} 
Özellikle kırsal bölgelerde, mirasbırakan, maliki olduğu tarım arazisini hayatta iken o arazi ile en fazla ilgilenen, emek ve para harcayan hatta bazen araziye köy/ çiftlik evi inşa eden çocuğuna bırakmayı tercih etmektedir; ancak devir taahhüdü ivazsız olmasına rağmen tapuda satış sözleşmesi şeklinde düzenlendiğinde işlem muvazaalı hale gelmektedir. Ne var ki yukarıda da açıladığımız üzere ${ }^{136}$, muris muvazaası nedeniyle işlemin geçersiz kılınabilmesi için öncelikle mirasbırakanın diğer mirasçılardan mal kaçırma kastı olması aranır. Her somut olayda hakim, mirasbırakanın mal kaçırma kastının olup olmadığını tespit ederken yine yukarıda da belirttiğimiz çeşitli kıstasları dikkate alır. Bölgenin gelenekleri, mirasbırakanın makul ve haklı nedeni gibi durumları göz önünde tutarak, hakim, tarım arazisine ilişkin muvazaalı işlemde, mal kaçırma kastının olmadığına karar verebilir. Örneğin, ailenin en büyük çocuğuna işletmekte olduğu tarım arazisini bırakmak, bölge gelenekleri arasında sayılabilir.

Muvazaalı işlemin konusu, 5403 sayılı Kanun kapsamına giren bir tarım arazisi olduğunda, muris muvazaasının koşullarının gerçekleşip gerçekleşmediği incelenirken söz konusu Kanun hükümlerinin ve özellikle bu kapsamda tarım arazilerinin bütünlüğünün dikkate alınması gerekir. Tarım arazilerinin bütünlüğünün tehlikeye düşmesi halinde muris muvazaasının ileri sürülmesinin hakkın kötüye kullanılması oluşturduğu öğretide ileri sürülmüştür ${ }^{137}$. Benzer şekilde, bir babanın, tarım arazisinin mirasçılar arasında parçalanmasını önlemek amacıyla sağlığında, yasal sınırlar içinde, bir oğlu lehine bağışta bulunmasını ya da görünürde satış gerçekte bağış yapmasını, eşyanın niteliğine uygun bir işlem olarak tanımak gerektiği, ayrıca taşınmazların miras yoluyla aşırı ve ekonomik üretime imkan vermeyecek şekilde bölünmesinin ve parçalanmasının da üzerinde durulması gereken ciddi sosyal bir olay olduğu da öğretide ifade edilmiştir ${ }^{138}$.

5403 sayılı Kanun ile tarım arazilerinin devrinde ehil mirasçıya öncelik tanınması ve tarım arazilerinin bütünlüğünün korunmasına ilişkin kurallar emredici kurallardır. 5403 sayılı Kanun gereği, mirasbırakan, yapacağı ölüme bağlı tasarruf ile tarım arazisinin devredileceği ehil mirasçıyı kendisi de belirleyebilir. Bu konuda sulh hukuk hakimine itiraz edildiğinde (8/F/II), mirasbırakanın iradesi esas alınarak, bu itirazın konusu ve değerlendirilmesi ancak belirlenen mirasçının gerçekten ehil olup olmadığı ile ilgili olmalıdır ${ }^{139}$. Mirasbırakanın ehil mirasçıyı belirleme iradesini sağlararası bir işlemle ortaya koyması da evleviyetle mümkündür. Zira mirasbırakan sağlığında dilediği gibi tasarrufta bulunabilmektedir; bu tasarruflara karşı mirasçıların

\footnotetext{
$136 \mathrm{Bkz}$ II/A.

137 Kaplan (n 114) 368.

138 Yaşar Karayalçın, “ “16.3.1990 Tarih ve K. 1990/2 Sayılı İçtihadı Birleştirme Kararı” "Saklı Payı İhlal Edilmemiş Mirasçı Muvazaa Nedeniyle Dava Açabilir” Görüşü ve Diğer Problemler', (1991) Prof. Dr. Jale G. AKİPEK'e Armağan 209, 214. KARAYALÇIN'ın bu yöndeki görüşünün eleştirisi için bkz İsmet Sungurbey, 'Mirasbırakanın Danışıklı (Muvazaalı) İşlemleri Konusunda Sayın Prof. Dr. Yaşar Karayalçın'a Zorunlu Bir Yanıt' (1994) 6 Medeni Hukuk Sorunları 19, 58 vd.

$139 \mathrm{I} / \mathrm{B} / 3$
} 
miras payları ise denkleştirme ve tenkis hükümleri ile korunmaktadır. Bunun yanında mirasbırakanın yaptığı işlem muvazaalı ise tapu sicilinin düzeltilmesi için de dava açılabilir. Ancak muvazaalı işlemin konusu, 5403 sayılı Kanun kapsamında bir tarım arazisi ve tarafı da ehil mirasçı olduğunda, mal kaçırma kastının ve muris muvazaasının söz konusu olup olmadığı kanaatimizce tartışmalı hale gelir. Bu konudaki değerlendirmelerimizi aşağıda ayrı başlık altında açıklayacağız.

\section{Değerlendirme ve Sonuç}

5403 sayılı Kanun ile tarım arazilerinin ekonomik bütünlüğünün korunması ve işlevini kaybetmesine neden olacak şekilde parçalanmasının önlenmesi amaçlandığından, bu arazilerin miras yoluyla bölünmesinin önüne geçilmesi için öncelikle, varsa, bir ehil mirasçı tarafından işletilmesi gerekir. 5403 sayılı Kanun çerçevesinde, tarım arazilerinin bütünlüğünün korunması amacı doğrultusunda, gerektiğinde mülkiyet hakkına ve miras hukukuna ilişkin temel ilkelerden taviz verildiği görülmektedir.

Kanun’un amacı ve miras hukukuna ilişkin getirdiği hükümler dikkate alındığında, tarım arazilerinin ehil mirasçılara bırakılması önem arz eder ${ }^{140}$ ve bir ölüme bağlı tasarruf ile ehil mirasçı belirlendiğinde, söz konusu mirasçının gerçekten tarım arazilerini işletmede ehil olması koşuluyla, mirasbırakanın bu iradesine uygun hareket edilmektedir.

Mirasbırakan, tarım arazisini, tenkis kurallarını ihlal etmemek koşuluyla, sağlararası bir işlemle de devredebilir. Tarım arazisi, ivazsız bir şekilde bir mirasçıya devredildiğinde, yapılan sağlararası işlem, tenkis ve denkleştirme kurallarına tabi olmakla birlikte, kural olarak geçerlidir. Ancak mirasbırakan bu işlemi, muvazaalı bir şekilde de yapmış olabilir. 1974 tarihli İçtihadı Birleştirme Kararı gereğince mirasbırakanın yaptığı muvazaalı işlem, ancak mirasçılardan mal kaçırma kastı yoksa geçerli kabul edilir.

Muris muvazaasına ilişkin 1974 tarihli İçtihadı Birleştirme Kararı, mirasbırakanın iradesinin üstünlüğü, tasarruf özgürlüğ̈̈, saklı paylı mirasçıları özel olarak koruyan hükümlerin varlığı, ayrıca mirasbırakanın TMK 2/II'ye aykırı şekilde ileri süremeyeceği şekle aykırılığın, mirasçılar tarafından da ileri sürülememesi gerektiği vurgulanarak eleştirilmektedir. Kararın yerindeliği tartışmaya açık olmakla birlikte, en azından uygulandığı süreçte Türk Medeni Kanunu'nun miras hükümlerindeki ve diğer kanunlardaki değişiklikler dikkate alınarak, yeniden yorumlanması gerekir. $\mathrm{Bu}$ yorum yapılırken özellikle tarım arazilerinin bütünlüğünün korunması, mirasbırakanın saklı pay sınırları içerisinde sahip olduğu tasarruf özgürlüğü ve bu özgürlük çerçevesinde miras bırakanın ehil mirasçıyı belirleme iradesi dikkate alınmalıdır.

$140 \mathrm{Bkz} \mathrm{I} / \mathrm{B} / 3$. 
Buna göre özellikle saklı payı olmayan ya da ihlal edilmeyen mirasçıların muvazaa nedeniyle açtığı tapu sicilinin düzeltilmesi davasında, mirasbırakanın iradesine ve tasarruf özgürlüğüne üstünlük tanınabilir. Bu mirasçılar, koşulları varsa denkleştirme hükümlerine başvurabilirler.

Bununla birlikte muvazaalı işlemin konusu, 5403 sayılı Kanun kapsamında bir tarım arazisi ve tarafı da ehil mirasçı ise söz konusu kanun hükümlerinin emrediciliği ve Kanun'un amacı karşısında, davayı açan saklı pay sahibi mirasçılar dahi olsa, artık mal kaçırma kastından ve muris muvazaasından söz edilmemelidir. $\mathrm{Bu}$ halde mirasçılar, koşulları varsa tenkis ve denkleştirme hükümleri ile yeterince korunmaktadir.

Diğer taraftan muvazaalı işlemle tarım arazisi ehil olmayan bir mirasçıya devredilmişse ve diğer mirasçılar arasında tarım arazisini işletmeye istekli bir veya birden fazla ehil mirasçı varsa, bu halde sadece tenkis ve denkleştirme hükümlerine gidildiğinde tarım arazisinin ehil olmayan bir mirasçının elinde kalmasının önüne geçilemeyeceği için, muris muvazaasına dayanarak tapu sicilinin düzeltilmesi davası açılması ve tarım arazisinin terekeye dahil olması, 5403 sayılı Kanun'un amacı dikkate alındığında daha isabetli görülmektedir. Zira 5403 sayılı Kanun ile tarım arazisinin bölünmemesi ve öncelikli olarak bu konuda ehil bir kişinin yönetiminde olması amaçlanmaktadır.

Hakem Değerlendirmesi: Dış bağımsız.

Çıkar Çatışması: Yazarlar çıkar çatışması bildirmemiştir.

Finansal Destek: Yazarlar bu çalışma için finansal destek almadığını beyan etmiştir.

Peer-review: Externally peer-reviewed.

Conflict of Interest: The authors has no conflict of interest to declare.

Grant Support: The authors declared that this study has received no financial support. 


\section{Bibliyografya/Bibliography}

Acabey MB, 'Yargıtay Kararları Işığında Muris Muvazaası' iç Tuğçe Tuzcuoğlu ve A Hulki Cihan (edr), Yargıtay Kararları Işı̆̆ında Güncel Medeni Hukuk Problemleri Sempozyumu Bildirileri, 8-9 Kasım 2018 (On İki Levha 2019) 471-487.

Aday N, Taşınmaz Mülkiyetinin Naklinde Muvazaa (Kazancı Hukuk Yayınları 1992).

Akbulut PE, Borçlar Hukukunda Kesin Hükümsüzlük Yaptırımının Amaca Uygun Sinırlama (Teleolojik Redüksiyon) Yöntemi İle Daraltılması (On İki Levha 2016).

Antalya G ve Sağlam İ, Miras Hukuku (Legal 2015).

Atamulu İ, Türk Borçlar Hukukunda Muvazaa (Adalet 2017).

Ayan M, Eşya Hukuku-II- Mülkiyet (Seçkin 2016).

Ayan M, Miras Hukuku (Seçkin 2016).

Aybay A, Miras Hukuku Dersleri (Maltepe Üniversitesi Hukuk Fakültesi 2003).

Aydoğdu M, Yasadan ve Sözleşmeden Doğan Önalım Hakkı (Adalet 2013).

Bağc1 Ö, ‘Tarımsal Arazilerin Miras Yoluyla İntikali’ iç Tuğçe Tuzcuoğlu ve A Hulki Cihan (edr), Yargıtay Kararları Işı̆̆ında Güncel Medeni Hukuk Problemleri Sempozyumu Bildirileri, 8-9 Kasım 2018 (On İki Levha 2019) 71-76.

Çabri S, Miras Hukuku Şerhi C-1 (On İki Levha 2018).

Dural M ve Öz T, Türk Özel Hukuku Cilt IV Miras Hukuku (Filiz Kitabevi 2019).

Erdoğan K, 'Tarım Arazilerinin Miras Yolu İle İntikali'(2016) 24(1) Selçuk Üniversitesi Hukuk Fakültesi Dergisi 123-179.

Eren F, Borçlar Hukuku Genel Hükümler (Yetkin 2019).

Eren F, Borçlar Hukuku Özel Hükümler (Yetkin 2017).

Eren F/Başpınar V, Toprak Hukuku (Savaş 2017).

Erman H, Eşya Hukuku (Der 2017).

Ertaş Ş, Eşya Hukuku (Fakülteler Barış Kitabevi 2016).

Esener T, Türk Hususi Hukukunda Muvazaalı Muameleler (Ankara Üniversitesi Hukuk Fakültesi Yayınlar1 1956).

Eviz E, Muris Muvazaası (On İki Levha 2019).

Feyzioğlu FN, Borçlar Hukuku Genel Hükümler (İstanbul Üniversitesi Yayınları 1976).

Günay E, Yargıtay Kararları Eşliğinde Mirastan Mal Kaçırma (Tapulu Taşınmazlarda Muris Muvazaası) (Seçkin 2013).

Gürsoy KT, Eren F ve Cansel E, Türk Eşya Hukuku (Ankara Üniversitesi Hukuk Fakültesi Yayınları 1984).

Hatemi H, Miras Hukuku (On İki Levha 2018).

Hatemi H, Serozan R ve Arpacı A, Eşya Hukuku (Filiz Kitabevi 1991).

Hatemi H ve Gökyayla E, Borçlar Hukuku Genel Hükümler (Vedat 2017).

İmre Z ve Erman H, Miras Hukuku (Der 2018).

İnal E, 'Denkleştirme ve Tenkis Davalarında Parası Miras Bırakan Tarafından Ödenerek Mirasçılardan Biri Adına Alınan Taşınmazların Durumu' (2007) 65(2) İ̈HHFM 277-298.

İnan AN, Ertaş Ş ve Albaş H, İnan Türk Medeni Hukuku Miras Hukuku (Seçkin 2019).

Jäggi P, Gauch P and Hartmann S, Zürcher Kommentar Obligationenrecht Art. 18 OR, Auslegung Ergänzung und Anpassung der Verträge, Simulation, 4A (Schulthess 2014). 
Kaplan İ, 'Muris Muvazaası' (2016) 15(1) İKÜHFD (Prof. Dr. Turhan ESENER'e Armağan) 349369.

Karayalçın Y, 'Mirasçının Muvazaa Nedeniyle İptal Davası Açma Hakkı Var Mıdır? (1.10.1953, 11.4.1974 ve 22.6.1987 Tarihli İçtihadı Birleştirme Kararları)' (1989) Yasa Dergisi 323-337.

Karayalçın Y, “ “16.3.1990 Tarih ve K. 1990/2 Sayılı İçtihadı Birleştirme Kararı” "Saklı Payı İhlal Edilmemiş Mirasçı Muvazaa Nedeniyle Dava Açabilir” Görüşü ve Diğer Problemler', (1991) Prof. Dr. Jale G. AKİPEK'e Armağan 209-230.

Karayalçın Y, Mirasbırakanın Muvazaası Mı? Tasarruf Özgürlüğü ve Saklı Payın Korunması Mı? Bir Tartı̧̧ma (Turhan 2000).

Kılıçoğlu AM, Miras Hukuku (Turhan 2018).

Kilıçoğlu AM, Borçlar Hukuku Genel Hükümler (Turhan 2019).

Kramer E and Schmidlin B, Berner Kommentar, Allgemeine Einleitung in das schweizerische Obligationenrecht und Kommentar zu Art. 1-18 OR, Schweizerisches Zivilgesetzbuch, Das Obligationenrecht, Allgemeine Bestimmungen, Band/Nr. VI/1/1 (Stämpfli 1986).

Kocayusufpaşaoğlu N, Kocayusufpaşaoğlu/Hatemi/Serozan/Arpacı Borçlar Hukuku Genel Bölüm Borçlar Hukukuna Giriş Hukuki İ̧̧lem Sözleşme (Filiz Kitabevi 2014).

Kocayusufpaşaoğlu N, Miras Hukuku (Filiz Kitabevi 1987).

Kocayusufpaşaoğlu N, Miras Hukuku Ek Kitap (Filiz Kitabevi 1992).

Nomer H, Borçlar Hukuku Genel Hükümler (Beta 2019).

Oğuzman MK, Miras Hukuku (Filiz Kitabevi 1995).

Oğuzman MK, "Miras Bırakanın Gayrimenkule İlişkin Muvazaalı İşlemleri Bakımından Tenkis Davası ve Tapu Kaydının Tashihi Davası”, Prof. Dr. İlhan E. Postacıŏglu’na Armağan, İstanbul 1990, s. 187-199.

Oğuzman MK ve Öz T, Borçlar Hukuku Genel Hükümler Cilt-1 (Vedat 2019).

Oğuzman MK, Seliçi Ö ve Oktay-Özdemir S, Eşya Hukuku (Filiz Kitabevi 2019).

Oğuzman MK ve Barlas N, Medeni Hukuk (Vedat 2019).

Ozanemre Yayla HT, Mirasın Paylaşılması (Turhan 2011).

Özay OL, Tarım İşletmelerinin ve Arazilerinin Miras Yoluyla İntikali (Yetkin 2015).

Özbilen AB, Sözleşmelerin Şekli ve Şekil Yönünden Hükümsüzlüğü (On İki Levha 2016).

Özçelik ŞB, ‘5403 Sayılı Toprak Koruma ve Arazi Kullanımı Kanunu’nda 6537 Sayılı Kanun’la Yapılan Değişiklikler ve Değerlendirilmesi’ (2015) 19(1) Gazi Üniversitesi Hukuk Fakültesi Dergisi 87-110.

Özmen İ ve Özkaya E, Muvazaa Davaları (Adalet 1993).

Postacığlu İE, 'Namı Müstear ve Muvazaa Meseleleri Hakkında Yeni Görüşler' (1955) A. Samim Gönensay'a Armağan 164-193.

Reisoğlu S, Borçlar Hukuku Genel Hükümler (Beta 2012).

Ruhi C ve Ruhi AC, Muris Muvazaası (Seçkin 2017).

Sağlam İ, 'Tarımsal İşletmelerin Özgülenmesi Sorunu ve Bu Sorunun Tarım Reformu Açısından Değerlendirilmesi’ (2010) 16(1-2) MÜHFHAD 201-231.

Serozan R ve Engin İ, Miras Hukuku ve Uygulama Çalışmaları (Seçkin 2018).

Sert Sütçü S, Miras Bırakanın Muvazaalı Hukuki Işslemleri ve Sonuçları (Seçkin 2018). 
Sevinç Aydın B, 'Bekletici Sorun’ (2012) Selçuk Üniversitesi Sosyal Bilimler Enstitüsü, Yüksek Lisans Tezi $30<$ tez.yok.gov.tr >Erişim Tarihi 27.6.2019.

Sirmen L, Eşya Hukuku (Yetkin 2019).

Sungurbey İ, 'Mirasbırakanın Muvazaası Durumuna İlişkin Yargıtay’ın 1.4.1974 Gün 1/2 Sayılı Doğru İçtihadı Birleştirme Kararı Değiştirilemez’ (1994) 6 Medeni Hukuk Sorunları 7-18.

Sungurbey İ, 'Mirasbırakanın Danışıklı (Muvazaalı) İşlemleri Konusunda Sayın Prof. Dr. Yaşar Karayalçın’a Zorunlu Bir Yanıt' (1994) 6 Medeni Hukuk Sorunları 19-66.

Şen Doğramacı H, '6537 Sayılı Toprak Koruma ve Arazi Kullanımı Kanununda Değişiklik Yapılması Hakkında Kanunun Mülkiyet Hakkının Sınırlandırılmasına İlişkin Hükümlerinin Değerlendirilmesi' (2017) 13(2) Yeditepe Üniversitesi Hukuk Fakültesi Dergisi 69-94.

Tandoğan H, Borçlar Hukuku Özel Borç İlişkileri C.I/1 (Vedat 2008).

Tekinay SS, Akman S, Burcuoğlu H ve Altop A, Tekinay Borçlar Hukuku Genel Hükümler (Filiz Kitabevi 1993).

Tekinay SS, Akman S, Burcuoğlu H ve Altop A, Tekinay Eşya Hukuku (Filiz Kitabevi 1989).

Topçuoğlu H, Kanuna Karşı Hile (Kanundan Kaçınma Yolları) (Selüloz 1950).

Topuz M, 'Yargıtay Kararları Işı̆̆ında Muris Muvazaasının Varlığını Gösteren Emareler' (2016) 15(2-2) İKÜHFD (Prof. Dr. M. İlhan Ulusan'a Armağan Özel Sayı) 709-728.

Uyar Hatipoğlu Z, 'Yargıtay İçtihatlarına Göre Muris Muvazaasında Miras Bırakanın Asıl İradesinin Tayini’ (2017) 22(36) DÜHFD 109-135.

Uyumaz A ve İlhan O, 'Tarımsal Arazilerde Mülkiyetin Devri' (2018) 24(2) MÜHFHAD 877-878.

Von Tuhr A, Borçlar Hukukunun Umumi Kısmı Cilt: 1-2, Çeviren: Cevat Edege (Yargıtay Yayınları 1983).

Yavuz C ve Topuz M, 'Toprak Koruma ve Arazi Kullanımı Kanununda Değişiklik Yapılması Hakkında Kanun'un Türk Medeni Kanunu'nun Miras Hukukuna İlişkin Hükümlerinde Yaptığı Değişiklikler' (2015) 21(2) MÜHFHAD (Mehmet Akif Aydın'a Armağan) 663-700.

Yüce MB, '5403 Sayılı Toprak Koruma ve Arazi Kullanımı Kanunu ile Getirilen Kanuni Kisitlamalar' (2011) 10(2) İKÜHFD 105-140. 